

\title{
Experimental constraints on pre-eruption conditions of pantelleritic magmas: Evidence from the Eburru complex, Kenya Rift
}

\author{
Bruno Scaillet, Ray Macdonald
}

\section{- To cite this version:}

Bruno Scaillet, Ray Macdonald. Experimental constraints on pre-eruption conditions of pantelleritic magmas: Evidence from the Eburru complex, Kenya Rift. Lithos, 2006, 91, pp.1-4, 95-108. 10.1016/j.lithos.2006.03.010 . hal-00078804

\section{HAL Id: hal-00078804 \\ https://hal-insu.archives-ouvertes.fr/hal-00078804}

Submitted on 7 Jun 2006

HAL is a multi-disciplinary open access archive for the deposit and dissemination of scientific research documents, whether they are published or not. The documents may come from teaching and research institutions in France or abroad, or from public or private research centers.
L'archive ouverte pluridisciplinaire HAL, est destinée au dépôt et à la diffusion de documents scientifiques de niveau recherche, publiés ou non, émanant des établissements d'enseignement et de recherche français ou étrangers, des laboratoires publics ou privés. 


\title{
Experimental constraints on pre-eruption conditions of pantelleritic magmas: Evidence from the Eburru complex, Kenya Rift
}

\author{
Bruno Scaillet ${ }^{\mathrm{a}}{ }^{\mathrm{a}}$ and Ray Macdonald ${ }^{\underline{b}}$ \\ ${ }^{a}$ Institut des Sciences de la Terre d'Orléans, UMR 6113 CNRS-UO, 1a rue de la Férollerie, \\ 45071, Orléans cedex 02, France \\ ${ }^{\mathrm{b}}$ Environment Centre, Lancaster University, Lancaster LA1 4YQ, UK
}

\section{Abstract}

The phase relationships and compositions of a pantellerite from the Eburru complex in the Kenya Rift Valley have been determined at $150 \mathrm{MPa}$ and under reducing conditions, $2 \mathrm{log}$ units below the Ni-NiO solid buffer. The effects of temperature and melt water content on phase relationships have been explored. Alkali feldspar and quartz crystallise alone at temperatures above $700{ }^{\circ} \mathrm{C}$, irrespective of melt water content. Below $700{ }^{\circ} \mathrm{C}$, sodic amphibole and clinopyroxene also crystallise; the amphibole being the liquidus phase under water-rich conditions. The coexistence of amphibole phenocrysts with alkali feldspar and quartz in a crystal-poor pantellerite implies temperatures below $700{ }^{\circ} \mathrm{C}$ and melt water contents higher than $4 \mathrm{wt} . \%$, possibly up to 5-6wt.\%. Pantellerites have lower liquidus temperatures than associated comendites, which supports a parent-daughter relationship between the two magma types. The melts produced in the experiments extend the compositional trend displayed by the natural rock series, and reproduce some extreme compositions occasionally observed in alkaline volcanic series, with $\mathrm{FeO}$ contents above 12 wt. $\%$ and $\mathrm{Na}_{2} \mathrm{O}$ contents approaching $10 \mathrm{wt} . \%$. Pantellerites are therefore the true nearminimum melt compositions of alkaline oversaturated magma series.

Keywords: Peralkaline; Rhyolites; Pantellerite; Kenya; Volatiles

\section{Introduction}

Pantelleritic magmas are strongly peralkaline rhyolites having a $\left(\mathrm{Na}_{2} \mathrm{O}+\mathrm{K}_{2} \mathrm{O}\right) / \mathrm{Al}_{2} \mathrm{O}_{3}$ mol ratio (or agpaitic index, hereafter referred to as $\mathrm{AI}$ ) higher than 1.4. Together with comendites, the less strongly peralkaline rhyolite variety $(1<\mathrm{AI}<1.4)$, pantellerites usually occur in extensional tectonic settings, from oceanic islands (Ascension Island) to continental rift zones (Ethiopia, Kenya) and back arc settings (Mayor Island, New Zealand), generally in close spatial and temporal association with transitional basalts. Recent analytical studies have emphasised that peralkaline rhyolites, once thought to be relatively anhydrous (Bailey and Macdonald, 1987), may have in fact up to several wt.\% dissolved water under pre-eruptive conditions (Harris, 1986, Kovalenko et al., 1988, Lowenstern and Mahood, 1991, Webster et

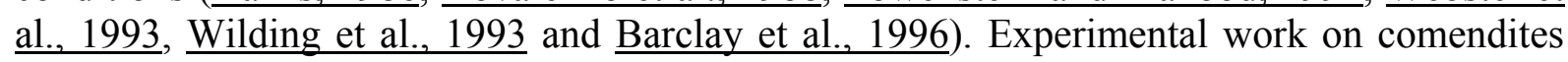
from the Olkaria volcanic complex, Kenya, has confirmed the water-rich nature of peralkaline rhyolites, as well as the usual corollary, the rather low temperatures of equilibration (Scaillet and Macdonald, 2001 and Scaillet and Macdonald, 2003). For the comendites studied, it was found that phase equilibrium constraints demand pre-eruptive temperatures to be lower than $750{ }^{\circ} \mathrm{C}$, and possibly as low as $660^{\circ} \mathrm{C}$. Such low temperatures conflict with the widely held view that peralkaline silicic magmas are among the highest temperature rhyolites, which 
would explain certain unusual volcanological features, such as their forming rheomorphic ignimbrites, by allowing extremely fluid behaviour during emplacement.

Although some progress has been made with respect to the volatile contents of peralkaline rhyolitic magmas, little is known, by comparison, of the temperature range over which such magmas evolve and/or are stored. This is largely due to the infrequency of coexisting oxide in such rocks, preventing application of the well-calibrated FeTi oxide thermobarometer (Andersen and Lindsley, 1988 and Ghiorso and Sack, 1991), a feature stressed more than 40 years ago by Carmichael (1962). There has been no detailed work on the phase equilibria of natural pantellerites, other than the exploratory studies of Bailey and coworkers (Bailey, 1974, Bailey et al., 1974 and Bailey and Cooper, 1978). As a consequence, although some insight is being gained through the application of alternative mineral equilibria (i.e. hedenbergite-fayalitic olivine and aenigmatite), the pre-eruption temperatures and water contents of pantellerites worldwide are not well established. This study aims to provide constraints on this issue, using the phase equilibrium approach that has proven useful in assessing the magmatic conditions of comendites (Scaillet and Macdonald, 2001).

We have determined the phase relationships of a pantellerite from the Eburru volcanic complex, which is located north of the Olkaria volcanic field in the Kenya rift on which our previous experimental efforts have been focused (Scaillet and Macdonald, 2001 and Scaillet and Macdonald, 2003). The study is a continuation of on-going work directed at understanding the mechanisms by which peralkaline silicic magmas are produced (e.g. Davies and Macdonald, 1987, Macdonald et al., 1987 and Heumann and Davies, 2002) and the conditions of magma storage in the crust. In our previous work, we systematically explored the effects of pressure, temperature, water content and $\mathrm{fO}_{2}$ on phase equilibria and phase compositions, including the melts produced by extreme fractionation of marginally to moderately peralkaline rhyolites (comendites). Here we restrict our attention to the role played by variations in both melt water content and temperature in pantelleritic magmatism. We keep total pressure constant at $150 \mathrm{MPa}$ and $\mathrm{fO}_{2}$ at around $\mathrm{NNO}-2\left(f \mathrm{O}_{2}\right.$ is referenced to the Ni-NiO solid buffer, so that NNO-2 means an $\mathrm{fO}_{2} 2$ log units below NNO at the chosen $P$ and $T$ ), the values chosen for these two parameters being in agreement with those commonly accepted for peralkaline rhyolites, i.e. low pressure of magma storage (Mahood, 1984) and somewhat reducing conditions (see Scaillet and Macdonald, 2001), and in line with our previous findings on the $\mathrm{P}-\mathrm{fO}_{2}$ conditions of comendites (Scaillet and Macdonald, 2001). Note that in the present report, as in our previous studies (Scaillet and Macdonald, 2001 and Scaillet and Macdonald, 2003), the parameter which is fixed during the experiments is the hydrogen fugacity $\left(\mathrm{fH}_{2}\right)$. As explained below in detail, the $\mathrm{fO}_{2}$ in our charges varied according to the water activity (variable melt water content). As a result, the phase equilibria reported here encompass a range of $\mathrm{fO}_{2}$. However, given the overall reducing conditions investigated (NNO-1 to NNO-4), the variation in $\mathrm{fO}_{2}$ should be accompanied by minor changes in the $\mathrm{Fe}^{2+} / \mathrm{Fe}^{3+}$ ratio (i.e. almost all iron in the melt is $\mathrm{Fe}^{2+}$ ) so variations in experimental $\mathrm{fO}_{2}$ are expected to have little effect on observed phase equilibria. 


\section{Geological background and selected sample}

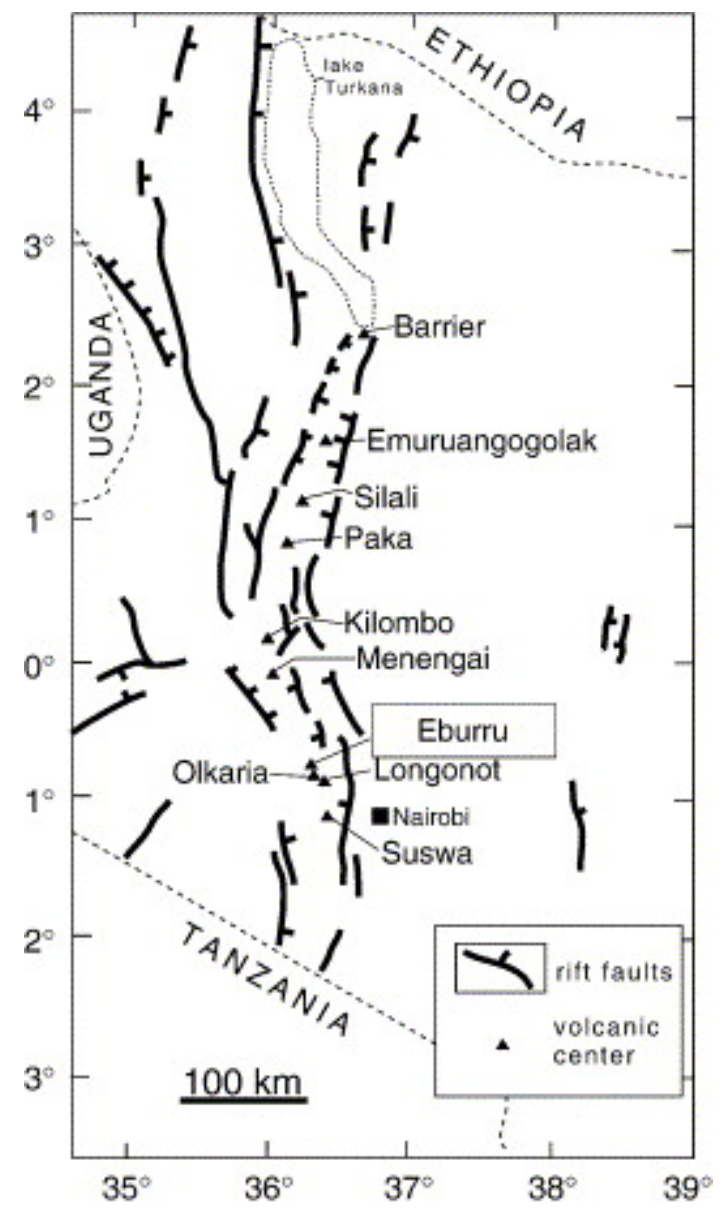

Fig. 1. Locality map of the Eburru and Olkaria rhyolitic complexes and of the nearby trachytic caldera volcanoes Longonot and Suswa. Also shown are the main Quaternary volcanic centres of the Kenya rift

The Eburru Volcanic Complex is located NW of Lake Naivasha (Fig. 1). Its southern boundary coincides with the northern boundary of the Olkaria field. Its age is not known in detail. According to Clarke et al. (1990), all units are thought to be $<0.45 \mathrm{Ma}$ and the youngest eruptives probably no more than a few hundred years old. Ren et al. (2006-this issue), however, report that the complex was initiated prior to $1.2 \mathrm{Ma}$. Lithologically, Eburru is composed almost entirely of peralkaline trachytes and rhyolites of pantelleritic affinity. Two groups, members of which have been available for eruption throughout much of the history of the complex, have been distinguished by Clarke et al. (1990); the Eburru Trachyte and the Eburru Pantellerite. On an $\mathrm{FeO}-\mathrm{Al}_{2} \mathrm{O}_{3}$ plot, the Eburru Trachyte straddles the boundary between pantelleritic trachyte and pantellerite, whereas the Eburru Pantellerite plots entirely within the pantellerite field, parallel to, but displaced below, the Eburru Trachyte (see Fig. 7). This feature alone precludes a direct genetic connection between the trachytes and rhyolites. 
Table 1. : Composition of the starting material

\begin{tabular}{|c|c|c|}
\hline & Eburru-89a & This study ${ }^{b}$ \\
\hline $\mathrm{SiO}_{2}$ & 70.86 & 71.25 \\
\hline $\mathrm{Al}_{2} \mathrm{O}_{3}$ & 8.48 & 8.03 \\
\hline $\mathrm{FeO}$ & 5.02 & 4.23 \\
\hline $\mathrm{Fe}_{2} \mathrm{O}_{3}$ & 2.40 & 3.00 \\
\hline $\mathrm{FeO}_{\text {tot }}$ & 7.18 & 6.93 \\
\hline $\mathrm{MgO}$ & 0.52 & 0.01 \\
\hline $\mathrm{MnO}$ & 0.25 & 0.21 \\
\hline $\mathrm{CaO}$ & 0.30 & 0.33 \\
\hline $\mathrm{Na}_{2} \mathrm{O}$ & 6.68 & 6.54 \\
\hline $\mathrm{K}_{2} \mathrm{O}$ & 4.50 & 4.60 \\
\hline $\mathrm{TiO}_{2}$ & 0.33 & 0.30 \\
\hline $\mathrm{ZrO}_{2}$ & - & 0.29 \\
\hline $\mathrm{Cl}$ & 0.42 & 0.40 \\
\hline $\mathrm{F}$ & 0.69 & 1.10 \\
\hline $\mathrm{O}=\mathrm{F}, \mathrm{Cl}$ & 0.39 & 0.55 \\
\hline Total & 100.06 & 99.44 \\
\hline
\end{tabular}

${ }^{a}$ From Macdonald and Bailey (1973, Table 3, no. 89) and Bailey and Macdonald (1975) for F and $\mathrm{Cl}$ analyses.

${ }^{\mathrm{b}}$ Average of 6 EMP analyses.

\section{Experimental and analytical techniques}

Powdered obsidian glass $(20 \mathrm{mg})$ was loaded into Au capsules $(1.5 \mathrm{~cm}$ length, wall thickness $0.2 \mathrm{~mm}$ and outer diameter $2.9 \mathrm{~mm}$ ). Prior to the glass powder, distilled $\mathrm{H}_{2} \mathrm{O}$ with or without $\mathrm{CO}_{2}$ (added as silver oxalate) was inserted at the bottom of the capsule $\left(2 \mathrm{mg} \mathrm{H}_{2} \mathrm{O}+\mathrm{CO}_{2}\right)$. Some charges were loaded with only the nominally dry glass powder (which in fact has 0.2 wt. $\%$ dissolved $\mathrm{H}_{2} \mathrm{O}$, as determined by several Karl Fischer titrations, plus 0.2 wt.\% of adsorbed $\mathrm{H}_{2} \mathrm{O}$ which is the water released at $120{ }^{\circ} \mathrm{C}$ during the titration). Once fully loaded, the capsules were welded shut using a graphite arc welder. The weight of the capsules was used as a monitor of volatile loss during welding. All charges reported in this work showed, upon welding or after being run at $P$ and $T$, no weight changes in excess of $0.2 \mathrm{mg}$, which is within the analytical uncertainty of the balance. Experiments were performed either with cold seal pressure vessels (CSPV) or with an internally high-pressured vessel (IHPV), both fitted with an $\mathrm{H}_{2}$ membrane to monitor the $\mathrm{H}_{2}$ fugacity of the runs. Details of the procedure for the use of the vessels and accompanying furnaces are given in Scaillet et al. (1992) and Schmidt et al. (1995). Uncertainties in temperature reported in this work are estimated to be $\pm 8^{\circ} \mathrm{C}$ for CSPV and $\pm 5^{\circ} \mathrm{C}$ for IHPV. 
The pressurizing medium was always an $\mathrm{Ar}-\mathrm{H}_{2}$ mixture, obtained either via sequential loading of $\mathrm{H}_{2}$ and then Ar at room temperature (IHPV) or via $\mathrm{H}_{2}$ supply through the $\mathrm{H}_{2}$ membrane at $P$ and $T(\mathrm{CSPV})$. The uncertainty in total pressure is estimated to be $\pm 3 \mathrm{MPa}$, whilst that on $\mathrm{H}_{2}$ fugacity is $0.01 \mathrm{MPa}$. Runs performed within CSPV involved 1 to 3 capsules, whilst those in IHPV had 6 capsules. Run durations varied according to temperature between $1193 \mathrm{~h}\left(650^{\circ} \mathrm{C}\right)$ and $197 \mathrm{~h}\left(800^{\circ} \mathrm{C}\right)$. Runs were terminated by either switching off the power supply and letting the vessel cool down at its own pace (IHPV), or by removing the vessel from the furnace (CSPV). Both quenches resulted in cooling rates on the order of 50 $100^{\circ} \mathrm{C} / \mathrm{min}$, with the IHPV imposing slightly faster cooling rates than the CSPV. The pressure drop during quench until the glass transition temperature (c. $300-400{ }^{\circ} \mathrm{C}$ ) was reached was c. $15 \mathrm{MPa}$ for the CSPV and $30 \mathrm{MPa}$ for the IHPV.

Upon completion of the run, capsules were weighed to check for leaks and opened. During opening, evidence for excess fluid was looked for using two criteria: outbursts of water drops and hissing, especially for $\mathrm{CO}_{2}$-bearing charges. Charges which were loaded with only water at amounts below $\mathrm{H}_{2} \mathrm{O}$ saturation (as inferred from $\mathrm{H}_{2} \mathrm{O}$ saturated runs, see below) did not show the above features of fluid saturation, as expected. For all capsules, a smell of $\mathrm{H}_{2} \mathrm{~S}$ was noted, indicating the presence of reduced sulphur in the charges. Polished probe mounts were then prepared using approximately half the run products, the remainder being used for direct optical investigation or additional analyses, if deemed necessary.

Run products were characterised by scanning electron microscopy (SEM) and electron microprobe analysis (EMPA). Analytical conditions for EMPA were accelerating voltage $15 \mathrm{kV}$, sample current $6 \mathrm{nA}$, counting time $10 \mathrm{~s}$ on peak for all elements and a focused beam for minerals. For glasses, the beam was defocused to $5 \mu \mathrm{m}$. $\mathrm{Na}$ and $\mathrm{K}$ were analysed first and a ZAF correction procedure was applied. A series of hydrous glass standards with known water content, made from the Eburru obsidian, was used to determine the empirical correction factor to be applied to the sodium content of the experimental glasses. This series was prepared with variable $\mathrm{H}_{2} \mathrm{O}$ contents in Au capsules and annealed at $200 \mathrm{MPa}$ and $850{ }^{\circ} \mathrm{C}$ for a week in a CSPV and drop quenched. Under the above analytical conditions, empirical correction factors varied from 1.05 for melt water contents lower than $2 \mathrm{wt} . \%$, to 1.35 for melt water contents of 6-7 wt.\%. Apart from $\mathrm{Na}$, no significant variation in the abundance of any element was noted with variations in $\mathrm{H}_{2} \mathrm{O}_{\text {melt }}$.

Melt $\mathrm{H}_{2} \mathrm{O}$ contents were determined using the by-difference method (see $\underline{\text { Scaillet and }}$ Macdonald, 2001), and via mass balance constraints, assuming perfectly incompatible behaviour of $\mathrm{H}_{2} \mathrm{O}$ (except for $\mathrm{CO}_{2}$-bearing charges, see below). In the latter case, the amount of residual melt was determined by mass balance, using phase compositions as determined by EMPA. In the mass balance approach, it was assumed that the bulk water content of the charge consisted of the $\mathrm{H}_{2} \mathrm{O}$ loaded to the capsule, plus that already dissolved or adsorbed in the natural glass $\left(0.4\right.$ wt. $\left.\% \mathrm{H}_{2} \mathrm{O}\right)$. We further considered the reduction of $\mathrm{Fe}_{2} \mathrm{O}_{3}$ to $\mathrm{FeO}$ as a possible source of water. Given that the starting glass contains $4.2 \mathrm{wt} . \% \mathrm{FeO}$, as determined by wet chemistry, this implies that the $3 \mathrm{wt} . \%$ of $\mathrm{Fe}_{2} \mathrm{O}_{3}$ originally present in the glass can yield 0.37 wt. $\%$ additional water, should the reduction of $\mathrm{Fe}_{2} \mathrm{O}_{3}$ proceed to completion. The $\mathrm{H}_{2} \mathrm{O}$ contents of melts determined by both approaches generally agree to within $0.5 \mathrm{wt} . \%$ of each other, except for the most crystal-rich charges, for which the by-difference approach yields melt $\mathrm{H}_{2} \mathrm{O}$ contents $1-2 \mathrm{wt} . \%$ higher than those via mass balance. SEM observations reveal that these crystal-rich charges are often packed with $\mu \mathrm{m}$-sized bubbles of inferred quench origin (Scaillet and Macdonald, 2001 and Scaillet and Macdonald, 2003). As a result, broad beam EMPA analyses end up producing exceedingly low totals and thus spuriously 
high melt $\mathrm{H}_{2} \mathrm{O}$ contents, much higher than permitted by the total amount of $\mathrm{H}_{2} \mathrm{O}$ of the system. Melt water contents of $\mathrm{H}_{2} \mathrm{O}$-saturated charges obtained at $800{ }^{\circ} \mathrm{C}$ and $750{ }^{\circ} \mathrm{C}$ and determined by-difference are 5.8 and $6.1 \mathrm{wt} . \%$, respectively, in reasonable agreement with previous estimates for similar compositions (Scaillet and Macdonald, 2001). In contrast, $\mathrm{H}_{2} \mathrm{O}-$ saturated charges synthetised at 700 and $650{ }^{\circ} \mathrm{C}$ display higher $\mathrm{H}_{2} \mathrm{O}$ contents (7-8 wt.\%). Although we cannot rule out that such an increase is due to a temperature effect, the rate of $\mathrm{H}_{2} \mathrm{O}$ increase with falling temperature is much higher than in metaluminous rhyolites (Johannes and Holtz, 1996). We thus suspect that the $\mathrm{H}_{2} \mathrm{O}$ content of low temperature charges is affected by quench processes, as in crystal-rich charges. For simplicity, however, we have assumed a constant melt water content of $6 \mathrm{wt} . \%$ at all temperatures, based on the by difference determination at $750{ }^{\circ} \mathrm{C}$ and $800{ }^{\circ} \mathrm{C}$ of $\mathrm{H}_{2} \mathrm{O}$-saturated charges. The water contents of $\mathrm{H}_{2} \mathrm{O}$-undersaturated charges with no $\mathrm{CO}_{2}$ used in this study are those obtained by mass balance. For $\mathrm{CO}_{2}$-bearing charges, we assumed that the following relationships holds:

$$
\text { wt. } \% \mathrm{H}_{2} \mathrm{O}=\mathrm{H}_{2} \mathrm{O}_{\text {sat }} \quad \mathrm{XH}_{2} \mathrm{O}_{\text {in }}
$$

where $\mathrm{XH}_{2} \mathrm{O}_{\text {in }}$ is the mole fraction of $\mathrm{H}_{2} \mathrm{O}$ of the starting fluid composition loaded to the charge. This relationship is equivalent to assuming ideal behaviour of water in the $\mathrm{CO}_{2}-\mathrm{H}_{2} \mathrm{O}$ fluid mixture. The method yields maximum estimates for $\mathrm{H}_{2} \mathrm{O}_{\text {melt }}$. Overall, melt water contents determined in this study are in the range $0.8-6 \mathrm{wt} . \%$.

For each charge, the determination of prevailing $\mathrm{fO}_{2}$ used the water dissociation reaction:

$$
\mathrm{H}_{2} \mathrm{O} \leftrightarrow \mathrm{H}_{2}+1 / 2 \mathrm{O}_{2}
$$

with thermodynamic data from Robie et al. (1979) for the dissociation constant, $K_{\mathrm{w}}$. For $\mathrm{H}_{2} \mathrm{O}-$ saturated charges, in addition to $K_{\mathrm{w}}$ we use the $\mathrm{fH}_{2}$ as given by membrane reading and $\mathrm{fH}_{2} \mathrm{O}$ of pure $\mathrm{H}_{2} \mathrm{O}$ at the $P$ and $T$ of the experiments, as given by Burnham et al. (1969). $\mathrm{For}_{2} \mathrm{O}-$ undersaturated charges, a complete $\mathrm{fO}_{2}$ calculation requires that $f \mathrm{H}_{2} \mathrm{O}$ be evaluated. Given that the activity-composition relationships of $\mathrm{H}_{2} \mathrm{O}$ in strongly peralkaline silicic melts are unknown, we have adopted the following procedure. We have assumed that the solubility of $\mathrm{H}_{2} \mathrm{O}$ in pantellerite obeys a power law of the form:

$$
f \mathrm{H}_{2} \mathrm{O}=a\left(\mathrm{H}_{2} \mathrm{O}_{\text {melt }}\right)^{b}
$$

where $a$ and $b$ are fitted parameters and $\mathrm{H}_{2} \mathrm{O}_{\text {melt }}$ is the wt. $\% \mathrm{H}_{2} \mathrm{O}$ dissolved in the melt. We fitted this function so that it yields a $\mathrm{H}_{2} \mathrm{O}$ solubility of $6 \mathrm{wt} . \%$ at $150 \mathrm{MPa}$ and $0.1 \mathrm{wt} . \%$ at atmospheric pressure. The resulting values for $a$ and $b$ coefficients were 52.7386 and 1.7221 , respectively. Next, using this empirical equation, $\mathrm{fH}_{2} \mathrm{O}$ can be calculated for any charge whose $\mathrm{H}_{2} \mathrm{O}$ content is known. Thereafter, the corresponding $\mathrm{fO}_{2}$ can be calculated using the water dissociation reaction and $\mathrm{fH}_{2}$, as explained above. The calculated $\mathrm{fO}_{2}$, given as $\triangle \mathrm{NNO}$ values, ranges from -0.69 at $\mathrm{H}_{2} \mathrm{O}$ saturation to -4.38 for the driest charges $(<1 \mathrm{wt} . \%$ $\mathrm{H}_{2} \mathrm{O}_{\text {melt }}$ ), with an average of -2.2 (Table 2). For convenience, we refer in the following to the redox conditions of this experimental study as being at an average $\mathrm{fO}_{2}$ of NNO-2. For $\mathrm{H}_{2} \mathrm{O}-$ saturated charges, the uncertainty in $\mathrm{fO}_{2}$ depends primarily on the uncertainty on the $\mathrm{H}_{2}$ fugacity and is estimated to be better than $0.1 \log$ unit. For $\mathrm{H}_{2} \mathrm{O}$-undersaturated charges, the uncertainty in $\mathrm{fO}_{2}$ is heavily dependent on that in $f \mathrm{H}_{2} \mathrm{O}$, which is not well known. However, charges whose $\mathrm{H}_{2} \mathrm{O}_{\text {melt }}$ exceeds 3 wt.\% differ in $\mathrm{fO}_{2}$ from the $\mathrm{H}_{2} \mathrm{O}$-saturated case by less than 
$0.5 \log$ unit (Table 2). It is for the driest charges $\left(\leq 1 \mathrm{wt} . \% \mathrm{H}_{2} \mathrm{O}_{\text {melt }}\right)$ that small variations in $\mathrm{H}_{2} \mathrm{O}_{\text {melt }}$ produce quite significant changes in $\mathrm{fO}_{2}$ and for these charges we estimate the uncertainty in $\mathrm{fO}_{2}$ to be of the order of $1 \log$ unit.

\section{Results}

\subsection{General}

The experimental conditions and run products of 26 successful experiments are listed in Table 2. Also given are the phase proportions obtained from mass balance calculations (Albarède, 1995). Calculations were performed using $\mathrm{SiO}_{2}, \mathrm{Al}_{2} \mathrm{O}_{3}, \mathrm{FeO}, \mathrm{MgO}, \mathrm{MnO}, \mathrm{CaO}, \mathrm{Na}_{2} \mathrm{O}, \mathrm{K}_{2} \mathrm{O}$ and $\mathrm{TiO}_{2}$ and take into account the propagation of the average analytical uncertainty of probe analyses. The data needed to determine phase proportions include the compositions of crystal and melt phases, as determined by EMPA, and the starting bulk rock composition (Table 1). The calculation is performed using matrix procedures, as explained in detail in Albarède (1995). Apart from two charges (\#1 and \#9), the sum of residuals $\left(r^{2}\right)$ is below 1 , indicating that the main phases have been identified. However, in some charges the incorporation of an additional Na-bearing phase significantly decreases the residuals (charges with $\mathrm{NaCl}$ in Table 2). This could imply either an underestimation of the $\mathrm{Na}$ correction factor during probe analysis of the residual melts or the possibility that $\mathrm{Na}$ has been partitioned into an unidentified phase which could be a fluid, a highly saline immiscible melt or a solid $(\mathrm{NaCl})$. For some charges at $\mathrm{H}_{2} \mathrm{O}$ saturation (\#1 and \#5), the second hypothesis seems plausible and is corroborated by the fact that $\mathrm{Cl}$ contents are lower than those calculated assuming perfectly incompatible behaviour, suggesting effective transport of a $\mathrm{NaCl}$ compound into a coexisting fluid or immiscible saline melt. However, above-liquidus $\mathrm{CO}_{2}$-bearing charges (\#6, \#7 and \#8) have $\mathrm{Cl}$ contents similar to that of the starting material (c. $0.39 \mathrm{wt} . \%$ ). Overall, the fact that $\mathrm{Cl}$ in the residual melts shows broadly incompatible behaviour (see below) suggests that, despite the care taken in glass analysis, some may have had their $\mathrm{Na}_{2} \mathrm{O}$ content slightly underestimated. 
Table 2. : Experimental conditions and run products

\begin{tabular}{|c|c|c|c|c|c|c|c|c|c|c|c|c|c|}
\hline Run & $\begin{array}{l}P_{\text {tot }} \\
\text { (bar) }\end{array}$ & \begin{tabular}{|l}
$T$ \\
$\left({ }^{\circ} \mathrm{C}\right)$
\end{tabular} & $\begin{array}{l}f \mathrm{H}_{2} \\
\text { (bar) }\end{array}$ & $\begin{array}{l}f \mathrm{H}_{2} \mathrm{O}^{\mathrm{a}} \\
\text { (bar) }\end{array}$ & $\log \mathrm{OO}_{2}$ & $\Delta \mathbf{N N O}^{\mathbf{b}}$ & $\mathrm{XH}_{2} \mathbf{O}_{\text {in }} \stackrel{\mathrm{c}}{ }$ & $\begin{array}{l}\mathrm{H}_{2} \mathrm{O}^{\mathrm{d}} \\
\text { (wt.\%) }\end{array}$ & $\begin{array}{l}\mathrm{CO}_{2}{ }^{\mathrm{e}} \\
\text { (wt. } \% \text { ) }\end{array}$ & $\mathrm{H}_{2} \mathbf{O}_{\text {melt }} \underset{\mathrm{f}}{\mathrm{f}}$ & $\begin{array}{l}\text { Duration } \\
\text { (h) }\end{array}$ & $r^{2}$ & Phases present and abundances (wt.\%) \\
\hline 1 & 1525 & 650 & 23 & 961 & -19.03 & -1.46 & 1 & 9.3 & - & 6.00 & 1193 & 1.02 & gl (92.9), vp, amph (5.9), nacl (1.2) \\
\hline 2 & 1525 & 650 & 23 & 903 & -19.08 & -1.51 & 0.94 & 7.8 & 1.2 & 5.64 & 1193 & 0.51 & $\mathrm{gl}(87.5), \mathrm{vp}, \mathrm{amph}(6.7), \mathrm{qz}(0.1)$, af (3.8), nacl (2.0) \\
\hline 3 & 1525 & 650 & 23 & 817 & -19.17 & -1.60 & 0.85 & 6.2 & 2.6 & 5.10 & 1193 & - & $\mathrm{gl}, \mathrm{vp}, \mathrm{amph}, \mathrm{aeg}, \mathrm{qz}, \mathrm{af}$ \\
\hline 4 & 1525 & 650 & 23 & 740 & -19.25 & -1.68 & 0.77 & 5.3 & 3.9 & 4.62 & 1193 & - & $\mathrm{gl}, \mathrm{vp}, \mathrm{amph}, \mathrm{aeg}, \mathrm{qz}, \mathrm{af}$ \\
\hline 5 & 1510 & 700 & 19 & 1056 & -17.33 & -1.15 & 1 & 10 & - & 6.00 & 807 & - & $\mathrm{gl}, \mathrm{vp}$ \\
\hline 6 & 1510 & 700 & 19 & 875 & -17.50 & -1.31 & 0.91 & 8.2 & 1.6 & 5.46 & 807 & - & $\mathrm{gl}, \mathrm{vp}$ \\
\hline 7 & 1510 & 700 & 19 & 817 & -17.56 & -1.37 & 0.85 & 6.5 & 2.7 & 5.10 & 807 & - & $\mathrm{gl}, \mathrm{vp}$ \\
\hline 8 & 1510 & 700 & 19 & 692 & -17.70 & -1.52 & 0.72 & 4.7 & 4.5 & 4.32 & 807 & - & $\mathrm{gl}, \mathrm{vp}, \mathrm{amph}(\mathrm{tr})$ \\
\hline 9 & 1510 & 700 & 19 & 139 & -19.10 & -2.91 & - & - & - & 1.76 & 807 & 1.85 & gl (43.9), vp, amph (7.6), qz (21.3), af (27.2) \\
\hline 10 & 1584 & 751 & 33 & 98 & -18.56 & -3.64 & - & - & - & 1.43 & 789 & 0.04 & gl (53.8), qz (17.2), af (29) \\
\hline 11 & 1526 & 775 & 33 & 74 & -18.22 & -3.86 & - & - & - & 1.22 & 240 & 0.11 & $\mathrm{gl}(63.1), \mathrm{qz}(14.7)$, af (22.2) \\
\hline 12 & 1526 & 775 & 33 & 245 & -17.18 & -2.82 & - & 1.6 & - & 2.44 & 240 & 0.36 & $\mathrm{gl}(97.2), \mathrm{qz}(1.8)$, af (1) \\
\hline 13 & 1546 & 801 & 34 & 51 & -17.97 & -4.18 & - & - & - & 0.99 & 240 & 0.07 & $\mathrm{gl}(78.1), \mathrm{qz}(9.3)$, af (12.6) \\
\hline 14 & 1546 & 801 & 34 & 233 & -16.65 & -2.87 & - & 1.6 & - & 2.37 & 240 & - & $\mathrm{gl}$ \\
\hline $15 b$ & 1541 & 825 & 37 & 44 & -17.65 & -4.38 & - & - & - & 0.90 & 197 & 0.23 & $\mathrm{gl}(85.7), \mathrm{qz}(6.5)$, af (7.8) \\
\hline 15 & 1525 & 750 & 13 & 74 & -18.01 & -3.07 & - & - & - & 1.22 & 286 & 0.09 & $\mathrm{gl}(63.0), \mathrm{qz}(13.4)$, af (23.6) \\
\hline 16 & 1525 & 750 & 13 & 247 & -16.97 & -2.03 & - & 1.3 & - & 2.45 & 286 & 0.46 & $\mathrm{gl}(84.4), \mathrm{qz}(6.3), \mathrm{af}(9.3)$ \\
\hline
\end{tabular}




\begin{tabular}{|c|c|c|c|c|c|c|c|c|c|c|c|c|c|}
\hline Run & $\begin{array}{l}P_{\text {tot }} \\
\text { (bar) }\end{array}$ & $\begin{array}{l}T \\
\left({ }^{\circ} \mathrm{C}\right)\end{array}$ & $\begin{array}{l}f \mathrm{H}_{2} \\
\text { (bar) }\end{array}$ & $\begin{array}{l}\mathrm{fH}_{2} \mathrm{O}^{\mathrm{a}} \\
\text { (bar) }\end{array}$ & $\log f \mathrm{O}_{2}$ & $\Delta \mathbf{N N O}^{\underline{b}}$ & $\mathrm{XH}_{2} \mathbf{O}_{\text {in }} \mathrm{c}$ & $\begin{array}{l}\mathbf{H}_{2} \mathbf{O}^{\mathbf{d}} \\
\text { (wt.\%) }\end{array}$ & $\begin{array}{l}\mathrm{CO}_{2}{ }^{\mathrm{e}} \\
\text { (wt. } \% \text { ) }\end{array}$ & $\mathbf{H}_{2} \mathbf{O}_{\text {melt }} \mathbf{f}$ & $\begin{array}{l}\text { Duration } \\
\text { (h) }\end{array}$ & $r^{2}$ & Phases present and abundances (wt.\%) \\
\hline 17 & 1525 & 750 & 13 & 301 & -16.79 & -1.86 & - & 1.9 & - & 2.75 & 286 & 0.02 & $\mathrm{gl}(97.1), \mathrm{qz}(2.1), \operatorname{nacl}(0.8)$ \\
\hline 18 & 1525 & 750 & 13 & 403 & -16.54 & -1.60 & - & 2.5 & - & 3.26 & 286 & - & $\mathrm{gl}, \mathrm{qz}(\mathrm{tr})$, nacl \\
\hline 19 & 1525 & 750 & 13 & 695 & -16.07 & -1.13 & - & 3.7 & - & 4.47 & 286 & - & $\mathrm{gl}$ \\
\hline 20 & 1525 & 750 & 13 & 1154 & -15.63 & -0.69 & - & 6.2 & - & 6.00 & 286 & - & $\mathrm{gl}, \mathrm{vp}$ \\
\hline 21 & 1550 & 800 & 13 & 37 & -17.45 & -3.65 & - & - & - & 0.81 & 208 & 0.07 & gl (95.2), qz (3.4), af (1.4) \\
\hline 22 & 1550 & 800 & 13 & 59 & -17.04 & -3.23 & - & 0.3 & - & 1.07 & 208 & - & $\mathrm{gl}, \mathrm{qz}(\mathrm{tr})$, nacl \\
\hline 23 & 1550 & 800 & 13 & 213 & -15.92 & -2.12 & - & 1.5 & - & 2.25 & 208 & - & gl, qz (tr), nacl \\
\hline 24 & 1550 & 800 & 13 & 344 & -15.50 & -1.70 & - & 2.2 & - & 2.97 & 208 & - & gl \\
\hline 25 & 1550 & 800 & 13 & 695 & -14.89 & -1.09 & - & 3.7 & - & 4.47 & 208 & - & $\mathrm{gl}$ \\
\hline 26 & 1550 & 800 & 13 & 545 & -15.10 & -1.30 & - & 6.2 & - & 3.90 & 208 & - & $\mathrm{gl}, \mathrm{vp}$ \\
\hline
\end{tabular}

tr: phase present in trace amounts. gl: glass; vp: vapour; amph: amphibole; af: alkali feldspar; qz: quartz; aeg: aegerine, nacl: sodium chloride. ${ }^{\text {a }} \mathrm{fH}_{2} \mathrm{O} \quad$ calculated

explained

${ }^{\mathrm{b}} \Delta$ NNO:
${ }^{\mathrm{c}}$ Initial
${ }^{\mathrm{d}}$ Weight

mole $^{\log \mathrm{fO}_{2}}$ fraction

relative

as

percent

of $\quad \mathrm{H}_{2} \mathrm{O}$

the value

e Weight

percent

of $\quad \mathrm{H}_{2} \mathrm{O}$

$\mathrm{H}_{2} \mathrm{O}$

the

fluid

phase

loaded

loaded

$\mathrm{CO}_{2}$

in

$\mathrm{Ni}-\mathrm{NiO}$

text.

Amount of dissolved $\mathrm{H}_{2} \mathrm{O}$ in the glass.

(1)


The crystalline phases identified are sodic amphibole, aegirine, alkali feldspar and quartz. Fluorite was formally detected in one charge (\#4) and, although no effort was made to systematically look for this mineral, we believe that its stability field is restricted to below $750{ }^{\circ} \mathrm{C}$ at all water contents, since no bright mineral in SEM images was seen in any of the charges run at or above $750{ }^{\circ} \mathrm{C}$. Glass was present in all charges, but could not be probed in charges \#3 and \#4, owing to their high crystallinity. All $\mathrm{CO}_{2}$-bearing or $\mathrm{H}_{2} \mathrm{O}$ saturated charges contained large bubbles $(>20 \mu \mathrm{m})$ indicative of fluid saturation. Charges that were supposed not to be saturated in fluid also contained small bubbles $(<10 \mu \mathrm{m})$, whose proportion is $1-3 \%$ by volume, regardless of charge crystallinity. The lack of variation with crystallinity of this population of bubbles suggests that they probably represent remnants of air bubbles originally trapped in the glass powder. Aegirine was positively identified only at $650{ }^{\circ} \mathrm{C}$ in the two driest charges (\#3 and \#4). No oxide was detected.

\subsection{Phase relationships}

The phase relationships are shown on Fig. 2. At $\mathrm{H}_{2} \mathrm{O}$ saturation, amphibole is the liquidus phase, crystallising slightly above $650^{\circ} \mathrm{C}$. It has not been found at temperatures higher than $700{ }^{\circ} \mathrm{C}$ and its stability field is drawn flat, although crystallisation of amphibole under very dry conditions $\left(<1 \mathrm{wt} \% \mathrm{H}_{2} \mathrm{O}\right.$ in melt) at temperatures higher than $700{ }^{\circ} \mathrm{C}$ cannot be excluded. Similarly, aegirine stability is restricted to below $700{ }^{\circ} \mathrm{C}$ but the stability field shown in Fig. 2 is only approximate. In particular, the extension or termination of this phase boundary in the high temperature and dry ranges are not constrained by the current data set. Below $700{ }^{\circ} \mathrm{C}$, quartz and alkali feldspar co-crystallise next to amphibole. Above $700{ }^{\circ} \mathrm{C}$, they both precede amphibole, quartz appearing slightly earlier than the alkali feldspar. At $800{ }^{\circ} \mathrm{C}$, quartz and alkali feldspar crystallise at melt $\mathrm{H}_{2} \mathrm{O}$ contents of 2 and $1 \mathrm{wt} . \%$, respectively. Extrapolation of the quartz boundary up-temperature suggests that the dry liquidus of the Eburru pantellerite is at, or above, $850^{\circ} \mathrm{C}$ at $150 \mathrm{MPa}$. Our data indicate that crystal-poor (i.e. near liquidus) pantelleritic magmas saturated in tectosilicates and amphibole require conditions of both low temperature $\left(650^{\circ} \mathrm{C}\right)$ and near $\mathrm{H}_{2} \mathrm{O}$ saturation $\left(>5\right.$ wt. $\left.\% \mathrm{H}_{2} \mathrm{O}\right)$.

The phase relationships in the Eburru pantellerite can be compared to those of Olkaria comendite SMN 29 studied by Scaillet and Macdonald (2001) at $150 \mathrm{MPa}$ and under slightly more oxidizing conditions (NNO-1.6). The boundaries of the main phases in both rhyolites are shown superimposed in Fig. 3. It is apparent that whilst the amphibole stability field occupies approximately the same position in both compositions, the liquidus curves of the tectosilicates are depressed by $30-40{ }^{\circ} \mathrm{C}$ in the Eburru pantellerite compared to the Olkaria comendite. This downward displacement can be due to the combined effects of the more strongly peralkaline character of, and the more reducing conditions applied to, the Eburru rock. However, given the rather modest difference in $\mathrm{fO}_{2}$ between the two studies (c. $0.5 \mathrm{log}$ unit), we suggest that the first effect is dominant. The fact that liquidus temperatures are lower in pantellerite than in comendite magma is in agreement with the demonstration that extensive crystallisation of comendite can produce pantellerite (Scaillet and Macdonald, 2003). The small difference in melt $\mathrm{H}_{2} \mathrm{O}$ content at saturation is not considered to be representative, given the error associated with the method of $\mathrm{H}_{2} \mathrm{O}$ determination in the experimental glasses. 


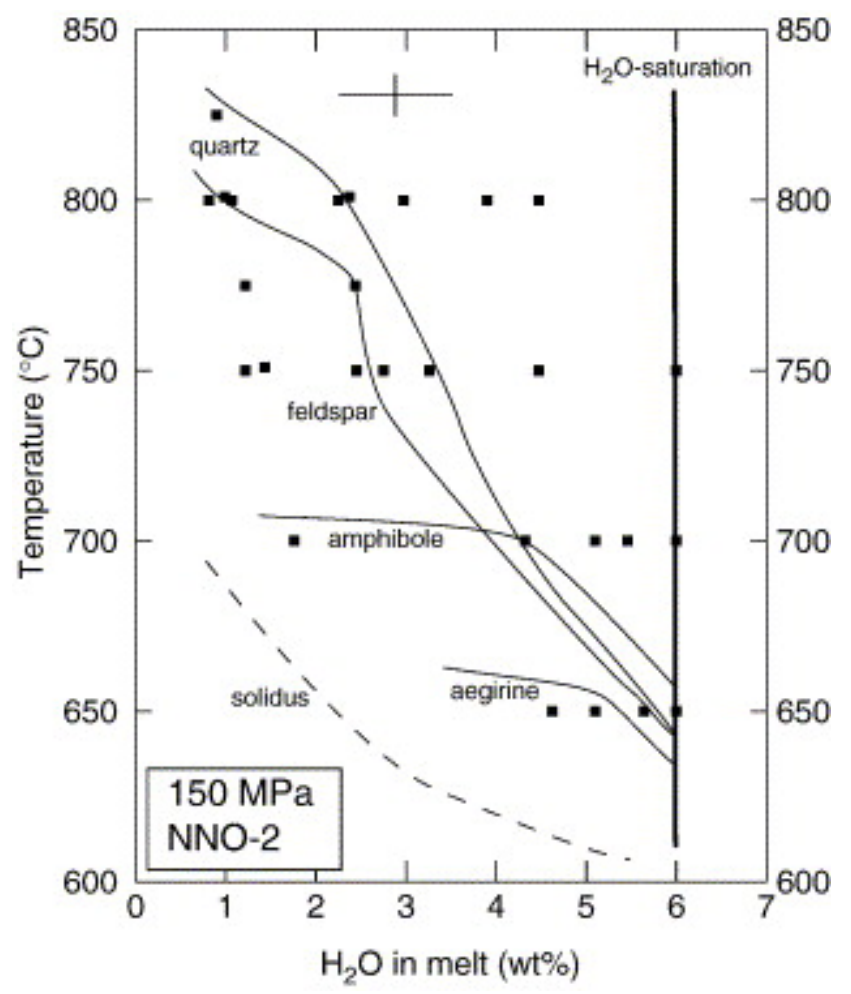

Fig. 2. Phase relationships of Eburru pantellerite at $150 \mathrm{MPa}$ and NNO-2.



Fig. 3. Comparison between the phase relationships of Eburru pantellerite (continuous lines) and those of Olkaria comendite (dashed lines), the latter taken from Scaillet and Macdonald (2001), rock composition SMN 49. Note the downward displacement of tectosilicate curves in Eburru pantellerite relative to Olkaria comendite 


\subsection{Phase abundances}

Mass balance calculations indicate that quartz and alkali feldspar are the dominant crystallising phases under all conditions except at near $\mathrm{H}_{2} \mathrm{O}$ saturation and low temperature, at around $650{ }^{\circ} \mathrm{C}$, where amphibole is the first phase to precipitate, reaching mass proportions of 6-7 wt.\%. The most highly crystallised charge (\#9, Table 2) has 44 wt.\% melt and contains $7.6 \mathrm{wt} . \%$ amphibole, in addition to quartz $(21.3 \mathrm{wt} . \%)$ and alkali feldspar (27.2 wt.\%). The fact that the proportion of amphibole does not increase significantly with crystallinity suggests that it probably does not crystallise in much higher abundance at lower melt fractions. Such a lack of increase might be due to a limitation of the bulk iron content available in the residual melt (and perhaps also to that of $\mathrm{Na}_{2} \mathrm{O}$ in excess of $\mathrm{Al}_{2} \mathrm{O} 3$ ), since amphibole crystallising in our experiments has FeOtot in excess of $30 \mathrm{wt} . \%$ (Table 3 ). In contrast, the non-increase in amphibole proportion cannot be attributed to a decrease in melt water content since as $\mathrm{H}_{2} \mathrm{O}_{\text {melt }}$ decreases, the water structurally bound in amphibole is exchanged with fluorine (i.e. the amphibole gets more F-rich, see next section) which helps stabilising sodic amphibole even in $\mathrm{H}_{2} \mathrm{O}$-poor magmas. Such a behaviour has been also noted for Olkaria comendites (Scaillet and Macdonald, 2001 and Scaillet and Macdonald, 2003). Thus, contrarily to arc magmas in which amphibole occurrence is generally taken as evidence of water-rich conditions, such a correlation is not always true for peralkaline rhyolites. Charges that crystallised aegirine could not be probed for their residual glasses, so the proportion of sodic pyroxene remains unknown. Fig. 4 shows the variation in the proportions of quartz and alkali feldspar with melt fraction. Both proportions increase almost linearly, although with different slopes, with decreasing melt fraction. Extrapolation of the quartz trend to the zero melt fraction intercept gives a quartz proportion at the solidus of $37 \mathrm{wt} . \%$, which is similar to granite. Similar extrapolation of alkali feldspar yields a proportion of $57 \mathrm{wt} . \%$, the remaining 6 wt.\% $\%=100-37-57)$ representing minor phases such as amphibole and aegirine. Amphibole precipitation produces a significant decrease of feldspar abundance relative to the trend drawn by amphibole-free charges (Fig. 4), which suggests that amphibole crystallises at the expense of feldspar-forming complexes in the melt.

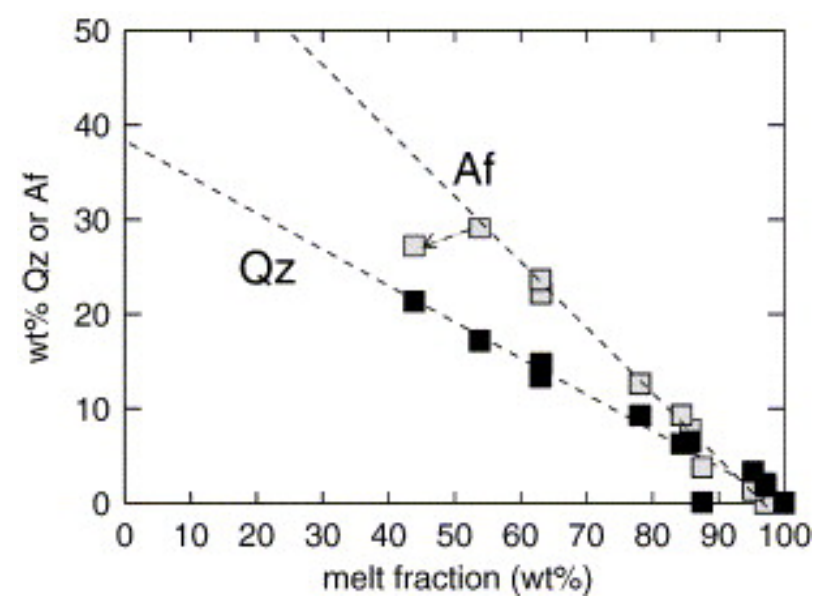

Fig. 4. Variations in quartz and alkali feldspar weight proportions with crystallisation. The dashed arrow shows the effect of amphibole crystallisation on the proportions of alkali feldspar. 
Table 3. : Representative compositions of amphibole and aegirine in Eburru experiments

\begin{tabular}{|c|c|c|c|c|c|c|c|c|}
\hline & \multicolumn{2}{|c|}{ Ebu-1 amph } & \multicolumn{2}{|c|}{ Ebu-2 amph } & \multirow{2}{*}{$\begin{array}{l}\text { Ebu-3 amph } \\
N=1\end{array}$} & \multicolumn{2}{|c|}{ Ebu-9 amph } & \multirow{2}{*}{$\begin{array}{l}\text { Ebu-3 aeg } \\
N=1\end{array}$} \\
\hline & $N=4$ & S.D. & $N=\mathbf{3}$ & S.D. & & $N=4$ & S.D. & \\
\hline $\mathrm{SiO}_{2}$ & 48.79 & 0.92 & 47.59 & 0.44 & 50.37 & 49.28 & 0.41 & 50.93 \\
\hline $\mathrm{TiO}_{2}$ & 1.05 & 0.17 & 1.24 & 0.12 & 0.79 & 1.72 & 0.22 & 1.08 \\
\hline $\mathrm{Al}_{2} \mathrm{O}_{3}$ & 0.85 & 0.29 & 0.59 & 0.09 & 1.36 & 0.56 & 0.23 & 0.46 \\
\hline $\mathrm{FeO}$ & 33.44 & 2.18 & 33.17 & 0.60 & 29.45 & 32.66 & 0.87 & 27.86 \\
\hline $\mathrm{MgO}$ & 0.13 & 0.03 & 0.11 & 0.04 & 0.16 & 0.14 & 0.06 & 0.05 \\
\hline $\mathrm{MnO}$ & 1.03 & 0.09 & 0.87 & 0.07 & 0.87 & 0.78 & 0.23 & 0.18 \\
\hline $\mathrm{CaO}$ & 0.93 & 0.16 & 0.50 & 0.13 & 0.45 & 0.93 & 0.09 & 0.84 \\
\hline $\mathrm{Na}_{2} \mathrm{O}$ & 7.55 & 0.34 & 7.63 & 0.48 & 9.32 & 7.89 & 0.11 & 12.40 \\
\hline $\mathrm{K}_{2} \mathrm{O}$ & 1.61 & 0.04 & 1.75 & 0.15 & 1.54 & 1.64 & 0.03 & 0.10 \\
\hline $\mathrm{ZrO}_{2}$ & 0.10 & 0.14 & 0.24 & 0.18 & 0.40 & 0.17 & 0.13 & 0.00 \\
\hline $\mathrm{Cl}$ & 0.03 & 0.02 & 0.02 & 0.01 & 0.03 & 0.02 & 0.03 & 0.01 \\
\hline $\mathrm{F}$ & 1.60 & 0.50 & 1.88 & 0.41 & 1.92 & 2.53 & 0.42 & 0.21 \\
\hline Total & 96.34 & & 94.56 & & 95.45 & 97.08 & 0.66 & 94.12 \\
\hline $\mathrm{Si}$ & 7.93 & & 7.89 & & 8.07 & 7.87 & & 2.02 \\
\hline $\mathrm{Ti}$ & 0.13 & & 0.15 & & 0.1 & 0.21 & & 0.02 \\
\hline $\mathrm{Al}$ & 0.16 & & 0.12 & & 0.26 & 0.11 & & 0.04 \\
\hline $\mathrm{Fe}^{2+}$ & 4.54 & & 4.6 & & 3.95 & 4.36 & & 0.14 \\
\hline $\mathrm{Fe}^{3+}$ & - & & - & & - & - & & 0.78 \\
\hline $\mathrm{Mg}$ & 0.03 & & 0.03 & & 0.04 & 0.03 & & 0.00 \\
\hline Mn & 0.14 & & 0.12 & & 0.12 & 0.11 & & 0.01 \\
\hline $\mathrm{Ca}$ & 0.16 & & 0.09 & & 0.08 & 0.16 & & 0.04 \\
\hline $\mathrm{Na}$ & 2.38 & & 2.45 & & 2.9 & 2.44 & & 0.95 \\
\hline K & 0.33 & & 0.37 & & 0.31 & 0.33 & & \\
\hline
\end{tabular}

Structural formulas are calculated based on $23 \mathrm{O}$ for amphibole and $6 \mathrm{O}$ for pyroxene. For amphibole, no attempt has been made to determine its $\mathrm{Fe}^{2+} / \mathrm{Fe}^{3+}$ ratio and the $\mathrm{Fe}$ is given as $\mathrm{Fe}^{2+}$. For clinopyroxene, $\mathrm{Fe}^{3+}$ is calculated assuming ideal pyroxene stoichiometry and using charge balance constraints. Totals given are corrected for F. The calculations do not incorporate $\mathrm{Zr}$ since its concentration is not known with great accuracy given the applied analytical conditions and the overall low concentrations of this element in experimental minerals. The pyroxene was assumed free of both $\mathrm{F}$ and $\mathrm{K}_{2} \mathrm{O}$, whose presence in the analysis is inferred to reflect glass contamination. 


\subsection{Phase compositions}

Alkali feldspar, amphibole, aegirine and glass were analysed (Table 3 and Table 4). Alkali feldspar was rather difficult to analyse, due to its small size and poor contrast with residual glass on BSE images, but the few acceptable analyses obtained reveal a constant composition at $\sim \mathrm{Or}_{40} \mathrm{Ab}_{60}$, with almost no detectable calcium. This composition is closely comparable to the phenocryst compositions in the natural rocks of similar AI (Ren et al., 2006-this issue).

Table 4. : Compositions of experimental glasses

\begin{tabular}{|c|c|c|c|c|c|c|c|c|c|c|c|c|c|}
\hline Sample & $\mathrm{SiO}_{2}$ & $\begin{array}{l}\mathrm{TiO} \\
2\end{array}$ & $\begin{array}{l}\mathbf{A l}_{2} \\
\mathbf{O}\end{array}$ & FeO & $\begin{array}{l}\text { Mg } \\
\text { O }\end{array}$ & $\begin{array}{l}\text { Mn } \\
\text { O }\end{array}$ & $\begin{array}{l}\mathrm{Ca} \\
\mathbf{O}\end{array}$ & $\begin{array}{l}\mathrm{Na}_{2} \\
\mathbf{O}\end{array}$ & $\begin{array}{l}\mathbf{K}_{2} \\
\mathbf{O}\end{array}$ & $\begin{array}{l}\mathrm{ZrO} \\
2\end{array}$ & Cl & $\mathbf{F}$ & $\begin{array}{l}\text { Origin } \\
\text { al total }\end{array}$ \\
\hline \multirow[t]{2}{*}{ Ebu-1 $(n=6)$} & $\begin{array}{l}74.5 \\
8\end{array}$ & 0.24 & 8.53 & 5.16 & 0.01 & 0.16 & 0.07 & 5.28 & $\begin{array}{l}4.3 \\
8\end{array}$ & 0.51 & $\begin{array}{l}0.1 \\
8\end{array}$ & $\begin{array}{l}0.9 \\
1\end{array}$ & 89.29 \\
\hline & 0.36 & 0.12 & 0.08 & 0.35 & 0.01 & 0.08 & 0.06 & 0.07 & $\begin{array}{l}0.1 \\
0\end{array}$ & 0.10 & $\begin{array}{l}0.0 \\
4\end{array}$ & $\begin{array}{l}0.0 \\
8\end{array}$ & \\
\hline \multirow[t]{2}{*}{ Ebu-2 $(n=6)$} & $\begin{array}{l}73.9 \\
8\end{array}$ & 0.21 & 8.70 & 5.26 & 0.01 & 0.22 & 0.09 & 5.32 & $\begin{array}{l}4.3 \\
2\end{array}$ & 0.45 & $\begin{array}{l}0.3 \\
2\end{array}$ & $\begin{array}{l}1.1 \\
2\end{array}$ & 89.54 \\
\hline & 0.15 & 0.07 & 0.17 & 0.12 & 0.01 & 0.07 & 0.07 & 0.14 & $\begin{array}{l}0.1 \\
6\end{array}$ & 0.19 & $\begin{array}{l}0.0 \\
6\end{array}$ & $\begin{array}{l}0.5 \\
7\end{array}$ & \\
\hline Ebu-4 & $\begin{array}{l}71.6 \\
3\end{array}$ & 0.32 & 9.11 & 6.15 & 0.00 & 0.34 & 0.01 & 5.49 & $\begin{array}{l}4.4 \\
5\end{array}$ & 0.91 & $\begin{array}{l}0.4 \\
2\end{array}$ & $\begin{array}{l}1.1 \\
9\end{array}$ & 86.24 \\
\hline \multirow[t]{2}{*}{ Ebu-5 $(n=6)$} & $\begin{array}{l}72.0 \\
0\end{array}$ & 0.31 & 8.09 & 6.96 & 0.01 & 0.17 & 0.25 & 5.79 & $\begin{array}{l}4.3 \\
4\end{array}$ & 0.48 & $\begin{array}{l}0.2 \\
8\end{array}$ & $\begin{array}{l}1.3 \\
2\end{array}$ & 91.39 \\
\hline & 0.50 & 0.07 & 0.13 & 0.16 & 0.02 & 0.13 & 0.05 & 0.40 & $\begin{array}{l}0.0 \\
9\end{array}$ & 0.19 & $\begin{array}{l}0.0 \\
3\end{array}$ & $\begin{array}{l}0.5 \\
8\end{array}$ & \\
\hline \multirow[t]{2}{*}{ Ebu-6 $(n=7)$} & $\begin{array}{l}72.0 \\
8\end{array}$ & 0.27 & 8.11 & 6.81 & 0.01 & 0.22 & 0.25 & 5.81 & $\begin{array}{l}4.4 \\
4\end{array}$ & 0.43 & $\begin{array}{l}0.3 \\
4\end{array}$ & $\begin{array}{l}1.2 \\
3\end{array}$ & 92.15 \\
\hline & 0.44 & 0.07 & 0.06 & 0.32 & 0.01 & 0.11 & 0.05 & 0.30 & $\begin{array}{l}0.1 \\
8\end{array}$ & 0.20 & $\begin{array}{l}0.0 \\
4\end{array}$ & $\begin{array}{l}0.6 \\
4\end{array}$ & \\
\hline \multirow[t]{2}{*}{ Ebu-7 $(n=7)$} & $\begin{array}{l}72.0 \\
2\end{array}$ & 0.28 & 8.02 & 6.92 & 0.02 & 0.20 & 0.22 & 5.86 & $\begin{array}{l}4.3 \\
1\end{array}$ & 0.45 & $\begin{array}{l}0.3 \\
7\end{array}$ & $\begin{array}{l}1.3 \\
4\end{array}$ & 92.93 \\
\hline & 0.48 & 0.03 & 0.13 & 0.22 & 0.01 & 0.05 & 0.08 & 0.37 & $\begin{array}{l}0.1 \\
1\end{array}$ & 0.12 & $\begin{array}{l}0.0 \\
4\end{array}$ & $\begin{array}{l}0.5 \\
3\end{array}$ & \\
\hline \multirow[t]{2}{*}{ Ebu-8 $(n=6)$} & $\begin{array}{l}71.4 \\
9\end{array}$ & 0.33 & 8.02 & 6.87 & 0.00 & 0.23 & 0.21 & 6.01 & $\begin{array}{l}4.5 \\
3\end{array}$ & 0.44 & $\begin{array}{l}0.3 \\
8\end{array}$ & $\begin{array}{l}1.4 \\
8\end{array}$ & 92.52 \\
\hline & 0.61 & 0.06 & 0.10 & 0.25 & 0.01 & 0.04 & 0.06 & 0.26 & $\begin{array}{l}0.1 \\
2\end{array}$ & 0.23 & $\begin{array}{l}0.0 \\
4\end{array}$ & $\begin{array}{l}0.4 \\
4\end{array}$ & \\
\hline Ebu-9 $(n=5)$ & $\begin{array}{l}63.5 \\
6\end{array}$ & 0.49 & 6.68 & 9.70 & 0.01 & 0.35 & 0.25 & 9.82 & $\begin{array}{l}4.7 \\
7\end{array}$ & 0.91 & $\begin{array}{l}0.8 \\
7\end{array}$ & $\begin{array}{l}2.5 \\
9\end{array}$ & 96.06 \\
\hline
\end{tabular}




\begin{tabular}{|c|c|c|c|c|c|c|c|c|c|c|c|c|c|}
\hline Sample & $\mathrm{SiO}_{2}$ & $\begin{array}{l}\text { TiO } \\
2\end{array}$ & $\begin{array}{l}\mathrm{Al}_{2} \\
\mathbf{O}\end{array}$ & $\mathrm{FeO}$ & $\begin{array}{l}\text { Mg } \\
\mathbf{O}\end{array}$ & $\begin{array}{l}\text { Mn } \\
\text { O }\end{array}$ & $\begin{array}{l}\mathrm{Ca} \\
\mathbf{O}\end{array}$ & $\begin{array}{l}\mathrm{Na}_{2} \\
\mathrm{O}\end{array}$ & $\begin{array}{l}\mathbf{K}_{2} \\
\mathbf{O}\end{array}$ & ${ }_{2}^{\mathrm{ZrO}}$ & $\mathbf{C l}$ & $\mathbf{F}$ & $\begin{array}{l}\text { Origin } \\
\text { al total }\end{array}$ \\
\hline & 3.73 & 0.16 & 1.98 & 1.81 & 0.01 & 0.08 & 0.09 & 0.97 & $\begin{array}{l}0.5 \\
3\end{array}$ & 0.16 & $\begin{array}{l}0.2 \\
4\end{array}$ & $\begin{array}{l}0.8 \\
7\end{array}$ & \\
\hline \multirow[t]{2}{*}{$\begin{array}{l}\text { Ebu-10 } \\
(n=4)\end{array}$} & $\begin{array}{l}64.2 \\
5\end{array}$ & 0.59 & 5.22 & $\begin{array}{l}12.2 \\
7\end{array}$ & 0.02 & 0.42 & 0.36 & 8.79 & $\begin{array}{l}4.4 \\
8\end{array}$ & 0.86 & $\begin{array}{l}0.8 \\
2\end{array}$ & $\begin{array}{l}1.9 \\
2\end{array}$ & 96.22 \\
\hline & 0.43 & 0.06 & 0.60 & 1.12 & 0.02 & 0.12 & 0.08 & 0.17 & $\begin{array}{l}0.4 \\
6\end{array}$ & 0.30 & $\begin{array}{l}0.0 \\
5\end{array}$ & $\begin{array}{l}0.3 \\
9\end{array}$ & \\
\hline \multirow[t]{2}{*}{$\begin{array}{l}\text { Ebu-11 } \\
(n=6)\end{array}$} & $\begin{array}{l}65.8 \\
2\end{array}$ & 0.51 & 6.26 & $\begin{array}{l}10.5 \\
6\end{array}$ & 0.03 & 0.40 & 0.31 & 7.96 & $\begin{array}{l}4.7 \\
4\end{array}$ & 0.66 & $\begin{array}{l}0.6 \\
8\end{array}$ & $\begin{array}{l}2.0 \\
7\end{array}$ & 95.92 \\
\hline & 0.34 & 0.11 & 0.38 & 0.46 & 0.02 & 0.10 & 0.04 & 0.10 & $\begin{array}{l}0.1 \\
8\end{array}$ & 0.37 & $\begin{array}{l}0.0 \\
7\end{array}$ & $\begin{array}{l}0.2 \\
9\end{array}$ & \\
\hline \multirow[t]{2}{*}{$\begin{array}{l}\text { Ebu-12 } \\
(n=5)\end{array}$} & $\begin{array}{l}71.1 \\
0\end{array}$ & 0.25 & 8.17 & 7.33 & 0.01 & 0.27 & 0.16 & 6.26 & $\begin{array}{l}4.6 \\
6\end{array}$ & 0.40 & $\begin{array}{l}0.4 \\
3\end{array}$ & $\begin{array}{l}0.9 \\
6\end{array}$ & 94.97 \\
\hline & 0.21 & 0.06 & 0.14 & 0.11 & 0.01 & 0.11 & 0.03 & 0.15 & $\begin{array}{l}0.0 \\
8\end{array}$ & 0.17 & $\begin{array}{l}0.0 \\
4\end{array}$ & $\begin{array}{l}0.4 \\
0\end{array}$ & \\
\hline \multirow[t]{2}{*}{$\begin{array}{l}\text { Ebu-13 } \\
(n=6)\end{array}$} & $\begin{array}{l}68.5 \\
5\end{array}$ & 0.39 & 7.24 & 8.63 & 0.02 & 0.27 & 0.27 & 7.40 & $\begin{array}{l}4.7 \\
7\end{array}$ & 0.51 & $\begin{array}{l}0.5 \\
8\end{array}$ & $\begin{array}{l}1.3 \\
9\end{array}$ & 95.53 \\
\hline & 0.40 & 0.06 & 0.31 & 0.31 & 0.01 & 0.07 & 0.06 & 0.17 & $\begin{array}{l}0.1 \\
3\end{array}$ & 0.14 & $\begin{array}{l}0.0 \\
3\end{array}$ & $\begin{array}{l}0.4 \\
7\end{array}$ & \\
\hline \multirow[t]{2}{*}{$\begin{array}{l}\text { Ebu-14 } \\
(n=6)\end{array}$} & $\begin{array}{l}72.0 \\
7\end{array}$ & 0.30 & 8.18 & 6.70 & 0.00 & 0.19 & 0.21 & 6.43 & $\begin{array}{l}4.4 \\
4\end{array}$ & 0.43 & $\begin{array}{l}0.3 \\
3\end{array}$ & $\begin{array}{l}0.7 \\
1\end{array}$ & 96.20 \\
\hline & 0.45 & 0.06 & 0.08 & 0.18 & 0.00 & 0.10 & 0.03 & 0.31 & $\begin{array}{l}0.0 \\
6\end{array}$ & 0.19 & $\begin{array}{l}0.0 \\
5\end{array}$ & $\begin{array}{l}0.4 \\
6\end{array}$ & \\
\hline \multirow[t]{2}{*}{$\begin{array}{l}\text { Ebu-15b } \\
(n=7)\end{array}$} & $\begin{array}{l}69.3 \\
1\end{array}$ & 0.39 & 7.55 & 7.97 & 0.02 & 0.30 & 0.19 & 6.73 & $\begin{array}{l}4.8 \\
3\end{array}$ & 0.57 & $\begin{array}{l}0.4 \\
7\end{array}$ & $\begin{array}{l}1.6 \\
7\end{array}$ & 97.77 \\
\hline & 0.63 & 0.06 & 0.14 & 0.24 & 0.02 & 0.09 & 0.07 & 0.15 & $\begin{array}{l}0.0 \\
9\end{array}$ & 0.19 & $\begin{array}{l}0.0 \\
6\end{array}$ & $\begin{array}{l}0.5 \\
0\end{array}$ & \\
\hline \multirow[t]{2}{*}{$\begin{array}{l}\text { Ebu-15 } \\
(n=7)\end{array}$} & $\begin{array}{l}66.1 \\
8\end{array}$ & 0.45 & 5.94 & $\begin{array}{l}10.6 \\
3\end{array}$ & 0.02 & 0.33 & 0.40 & 7.67 & $\begin{array}{l}4.4 \\
9\end{array}$ & 0.81 & $\begin{array}{l}0.7 \\
2\end{array}$ & $\begin{array}{l}2.3 \\
5\end{array}$ & 97.35 \\
\hline & 0.30 & 0.11 & 0.10 & 0.14 & 0.02 & 0.09 & 0.06 & 0.35 & $\begin{array}{l}0.1 \\
3\end{array}$ & 0.34 & $\begin{array}{l}0.0 \\
4\end{array}$ & $\begin{array}{l}0.6 \\
7\end{array}$ & \\
\hline \multirow[t]{2}{*}{$\begin{array}{l}\text { Ebu-16 } \\
(n=4)\end{array}$} & $\begin{array}{l}69.7 \\
2\end{array}$ & 0.35 & 7.66 & 8.38 & 0.02 & 0.26 & 0.28 & 6.41 & $\begin{array}{l}4.5 \\
9\end{array}$ & 0.63 & $\begin{array}{l}0.5 \\
3\end{array}$ & $\begin{array}{l}1.1 \\
6\end{array}$ & 96.07 \\
\hline & 0.42 & 0.04 & 0.14 & 0.26 & 0.01 & 0.06 & 0.04 & 0.12 & $\begin{array}{l}0.1 \\
2\end{array}$ & 0.15 & $\begin{array}{l}0.0 \\
4\end{array}$ & $\begin{array}{l}0.3 \\
2\end{array}$ & \\
\hline \multirow[t]{2}{*}{$\begin{array}{l}\text { Ebu-17 } \\
(n=8)\end{array}$} & $\begin{array}{l}71.2 \\
5\end{array}$ & 0.27 & 8.35 & 7.17 & 0.01 & 0.19 & 0.26 & 5.87 & $\begin{array}{l}4.6 \\
6\end{array}$ & 0.33 & $\begin{array}{l}0.4 \\
5\end{array}$ & $\begin{array}{l}1.1 \\
7\end{array}$ & 95.98 \\
\hline & 0.29 & 0.06 & 0.27 & 0.25 & 0.02 & 0.10 & 0.05 & 0.10 & $\begin{array}{l}0.1 \\
9\end{array}$ & 0.15 & $\begin{array}{l}0.0 \\
5\end{array}$ & $\begin{array}{l}0.6 \\
0\end{array}$ & \\
\hline Ebu-18 & 72.3 & 0.23 & 8.10 & 6.95 & 0.03 & 0.20 & 0.25 & 5.73 & 4.5 & 0.49 & 0.3 & 0.7 & 94.81 \\
\hline
\end{tabular}




\begin{tabular}{|c|c|c|c|c|c|c|c|c|c|c|c|c|c|}
\hline Sample & $\mathrm{SiO}_{2}$ & $\begin{array}{l}\text { TiO } \\
2\end{array}$ & $\begin{array}{l}\mathrm{Al}_{2} \\
\mathbf{O}\end{array}$ & $\mathrm{FeO}$ & $\begin{array}{l}\mathbf{M g} \\
\mathbf{O}\end{array}$ & $\begin{array}{l}\text { Mn } \\
\text { O }\end{array}$ & $\begin{array}{l}\mathrm{Ca} \\
\mathbf{O}\end{array}$ & $\begin{array}{l}\mathrm{Na}_{2} \\
\mathrm{O}\end{array}$ & $\begin{array}{l}\mathbf{K}_{2} \\
\mathbf{O}\end{array}$ & $\begin{array}{l}\mathrm{ZrO} \\
2\end{array}$ & Cl & F & $\begin{array}{l}\text { Origin } \\
\text { al total }\end{array}$ \\
\hline \multirow[t]{2}{*}{$(n=6)$} & 4 & & & & & & & & 2 & & 7 & 6 & \\
\hline & 0.33 & 0.08 & 0.13 & 0.18 & 0.02 & 0.13 & 0.03 & 0.13 & $\begin{array}{l}0.0 \\
9\end{array}$ & 0.29 & $\begin{array}{l}0.0 \\
4\end{array}$ & $\begin{array}{l}0.7 \\
9\end{array}$ & \\
\hline \multirow[t]{2}{*}{$\begin{array}{l}\text { Ebu-19 } \\
(n=7)\end{array}$} & $\begin{array}{l}71.8 \\
8\end{array}$ & 0.29 & 7.97 & 6.66 & 0.02 & 0.23 & 0.24 & 6.07 & $\begin{array}{l}4.4 \\
1\end{array}$ & 0.68 & $\begin{array}{l}0.4 \\
0\end{array}$ & $\begin{array}{l}1.1 \\
4\end{array}$ & 94.68 \\
\hline & 0.37 & 0.06 & 0.15 & 0.22 & 0.02 & 0.08 & 0.04 & 0.35 & $\begin{array}{l}0.0 \\
9\end{array}$ & 0.13 & $\begin{array}{l}0.0 \\
5\end{array}$ & $\begin{array}{l}0.7 \\
8\end{array}$ & \\
\hline \multirow[t]{2}{*}{$\begin{array}{l}\text { Ebu-20 } \\
(n=6)\end{array}$} & $\begin{array}{l}72.1 \\
9\end{array}$ & 0.27 & 8.04 & 6.99 & 0.02 & 0.22 & 0.23 & 6.10 & $\begin{array}{l}4.3 \\
5\end{array}$ & 0.53 & $\begin{array}{l}0.3 \\
6\end{array}$ & $\begin{array}{l}0.7 \\
0\end{array}$ & 92.01 \\
\hline & 0.70 & 0.06 & 0.15 & 0.32 & 0.01 & 0.10 & 0.04 & 0.38 & $\begin{array}{l}0.1 \\
6\end{array}$ & 0.25 & $\begin{array}{l}0.0 \\
4\end{array}$ & $\begin{array}{l}0.6 \\
2\end{array}$ & \\
\hline \multirow[t]{2}{*}{$\begin{array}{l}\text { Ebu-21 } \\
(n=6)\end{array}$} & $\begin{array}{l}69.9 \\
8\end{array}$ & 0.37 & 7.96 & 7.11 & 0.01 & 0.27 & 0.29 & 6.74 & $\begin{array}{l}4.8 \\
2\end{array}$ & 0.75 & $\begin{array}{l}0.5 \\
2\end{array}$ & $\begin{array}{l}1.1 \\
8\end{array}$ & 97.14 \\
\hline & 0.38 & 0.08 & 0.17 & 0.26 & 0.02 & 0.09 & 0.06 & 0.13 & $\begin{array}{l}0.1 \\
5\end{array}$ & 0.26 & $\begin{array}{l}0.0 \\
5\end{array}$ & $\begin{array}{l}0.4 \\
4\end{array}$ & \\
\hline \multirow[t]{2}{*}{$\begin{array}{l}\text { Ebu-22 } \\
(n=6)\end{array}$} & $\begin{array}{l}71.7 \\
7\end{array}$ & 0.28 & 8.24 & 6.17 & 0.01 & 0.27 & 0.25 & 6.15 & $\begin{array}{l}4.6 \\
4\end{array}$ & 0.37 & $\begin{array}{l}0.3 \\
9\end{array}$ & $\begin{array}{l}1.4 \\
6\end{array}$ & 97.09 \\
\hline & 1.82 & 0.06 & 0.31 & 0.36 & 0.01 & 0.10 & 0.08 & 0.19 & $\begin{array}{l}0.2 \\
3\end{array}$ & 0.32 & $\begin{array}{l}0.0 \\
4\end{array}$ & $\begin{array}{l}0.4 \\
7\end{array}$ & \\
\hline \multirow[t]{2}{*}{$\begin{array}{l}\text { Ebu-23 } \\
(n=6)\end{array}$} & $\begin{array}{l}72.2 \\
3\end{array}$ & 0.25 & 8.20 & 6.58 & 0.02 & 0.14 & 0.20 & 6.01 & $\begin{array}{l}4.5 \\
2\end{array}$ & 0.39 & $\begin{array}{l}0.3 \\
9\end{array}$ & $\begin{array}{l}1.0 \\
8\end{array}$ & 96.03 \\
\hline & 0.17 & 0.05 & 0.11 & 0.21 & 0.02 & 0.06 & 0.07 & 0.10 & $\begin{array}{l}0.0 \\
8\end{array}$ & 0.27 & $\begin{array}{l}0.0 \\
5\end{array}$ & $\begin{array}{l}0.6 \\
3\end{array}$ & \\
\hline \multirow[t]{2}{*}{$\begin{array}{l}\text { Ebu-24 } \\
(n=7)\end{array}$} & $\begin{array}{l}73.1 \\
8\end{array}$ & 0.28 & 8.19 & 5.77 & 0.01 & 0.15 & 0.24 & 5.96 & $\begin{array}{l}4.4 \\
6\end{array}$ & 0.48 & $\begin{array}{l}0.3 \\
7\end{array}$ & $\begin{array}{l}0.9 \\
3\end{array}$ & 96.02 \\
\hline & 0.31 & 0.05 & 0.05 & 0.35 & 0.01 & 0.10 & 0.05 & 0.26 & $\begin{array}{l}0.1 \\
8\end{array}$ & 0.15 & $\begin{array}{l}0.0 \\
3\end{array}$ & $\begin{array}{l}0.6 \\
0\end{array}$ & \\
\hline \multirow[t]{2}{*}{$\begin{array}{l}\text { Ebu-25 } \\
(n=5)\end{array}$} & $\begin{array}{l}71.8 \\
9\end{array}$ & 0.30 & 8.02 & 6.85 & 0.01 & 0.12 & 0.19 & 6.13 & $\begin{array}{l}4.5 \\
3\end{array}$ & 0.60 & $\begin{array}{l}0.3 \\
8\end{array}$ & $\begin{array}{l}0.9 \\
9\end{array}$ & 94.44 \\
\hline & 0.74 & 0.07 & 0.05 & 0.24 & 0.03 & 0.06 & 0.04 & 0.37 & $\begin{array}{l}0.0 \\
5\end{array}$ & 0.29 & $\begin{array}{l}0.0 \\
5\end{array}$ & $\begin{array}{l}0.3 \\
9\end{array}$ & \\
\hline \multirow[t]{2}{*}{$\begin{array}{l}\text { Ebu-26 } \\
(n=6)\end{array}$} & $\begin{array}{l}72.1 \\
9\end{array}$ & 0.23 & 8.07 & 6.62 & 0.00 & 0.12 & 0.22 & 6.31 & $\begin{array}{l}4.5 \\
3\end{array}$ & 0.49 & $\begin{array}{l}0.4 \\
0\end{array}$ & $\begin{array}{l}0.8 \\
1\end{array}$ & 94.50 \\
\hline & 1.14 & 0.05 & 0.09 & 0.21 & 0.01 & 0.04 & 0.04 & 0.25 & $\begin{array}{l}0.1 \\
2\end{array}$ & 0.27 & $\begin{array}{l}0.0 \\
7\end{array}$ & $\begin{array}{l}0.6 \\
5\end{array}$ & \\
\hline
\end{tabular}

The amphibole is always sodic and can be classified as arfvedsonite (Leake et al., 1997). It is Fe-rich, with $\mathrm{MgO}$ contents below 0.2 wt.\%, lower than $\mathrm{MnO}$ (0.7-1 wt.\%). Although it occurs over a limited $\mathrm{T}-\mathrm{H}_{2} \mathrm{O}$ range, the analyses reveal some distinct trends. At $650{ }^{\circ} \mathrm{C}$, 
amphibole crystallising near $\mathrm{H}_{2} \mathrm{O}$ saturation is richer in $\mathrm{Ca}$ than those near the solidus (compare \#1, \#2 and \#3, Table 3). Such a trend of decreasing $\mathrm{CaO}$ content with melt $\mathrm{H}_{2} \mathrm{O}$ content at fixed temperature has also been documented in amphibole crystallising in the Olkaria comendites (Scaillet and Macdonald, 2003). Similarly, the amphibole is F-rich, with F contents increasing with decreasing melt fraction, mirroring the increase in $\mathrm{F}$ of the coexisting melt. The mineral/melt partition coefficient for $\mathrm{F}$ ranges from 1.8 near the liquidus (\#1 and $\# 2)$ to 1 at higher melt fractions (\#9), similar to that at Olkaria (Scaillet and Macdonald, 2003). Despite the elevated $\mathrm{Cl}$ content of the coexisting melt, amphibole has almost no $\mathrm{Cl}$, as in Olkaria rocks and experiments (Macdonald et al., 1987 and Scaillet and Macdonald, 2003), but contains detectable amounts of $\mathrm{Zr}$. Its $\mathrm{TiO}_{2}$ content, in the range $0.8-1.7 \mathrm{wt} . \%$, shows no clear variation with changing melt fraction.

The few analyses of clinopyroxene show it to be sodic aegirine of nearly pure end-member composition (Table 3). The low total is presumably due to its high $\mathrm{Fe}^{3+}$ content, which amounts to $84 \%$ of total iron when calculated with stoichiometry and charge balance constraints (Table 3$)$.

The variation in glass composition (Table 4) with melt fraction is shown on Fig. $5 . \mathrm{K}_{2} \mathrm{O}$ remains remarkably constant over the crystallisation interval investigated. $\mathrm{SiO}_{2}$ and $\mathrm{Al}_{2} \mathrm{O}_{3}$ show a pronounced decrease with crystallisation, whilst $\mathrm{FeO}, \mathrm{Na}_{2} \mathrm{O}, \mathrm{CaO}, \mathrm{MnO}, \mathrm{TiO}_{2}$ and $\mathrm{ZrO}_{2}$ contents increase regularly. The trend of decreasing $\mathrm{SiO}_{2}$ and concomitant increase in $\mathrm{Na}_{2} \mathrm{O}$ are similar to those documented for Olkaria comendites (Macdonald et al., 1987 and Scaillet and Macdonald, 2003). The most peralkaline melt produced in our experiments has $\mathrm{AI}=3.4$, an $\mathrm{Al}_{2} \mathrm{O}_{3}$ content of $5.2 \mathrm{wt} . \%$, and a $\mathrm{FeO}$ content $>12 \mathrm{wt} . \%$, closely resembling analyses of melt inclusions and interstitial glasses in peralkaline rhyolites from the Azores (Mungall and Martin, 1996). It has also an elevated $\mathrm{ZrO}_{2}$ content, close to $1 \mathrm{wt} . \%$. The monotonous decreases or increases in element abundances are affected only by amphibole crystallisation. In particular, amphibole crystallisation at near-liquidus conditions, that is when only a minor proportion of quartz and alkali feldspar has crystallised, is able to drive the residual liquids toward compositions less peralkaline than the bulk starting material (Fig. 5), producing melts with AI values approaching the comendite-pantellerite divide line which, following Macdonald (1974), is set at $\mathrm{AI}=1.4$. This is due to the role that amphibole exerts on both $\mathrm{Na}_{2} \mathrm{O}$ and $\mathrm{Al}_{2} \mathrm{O}_{3}$ melt contents, the latter oxide being affected whether near-liquidus or crystal-rich conditions prevail, whilst the effect on $\mathrm{Na}_{2} \mathrm{O}$ is significant only under crystalpoor conditions (Fig. 5). Crystallisation of sodic amphibole buffers melt peralkalinity, preventing it from reaching the $\mathrm{Na}$ contents observed when only tectosilicate phases precipitate, as shown for the Olkaria comendites (Scaillet and Macdonald, 2003). Amphibole crystallisation in peralkaline rhyolites counteracts to some extent the so-called orthoclase effect on melt peralkalinity proposed by Bailey and Schairer (1964) and Bailey and Macdonald (1969). 

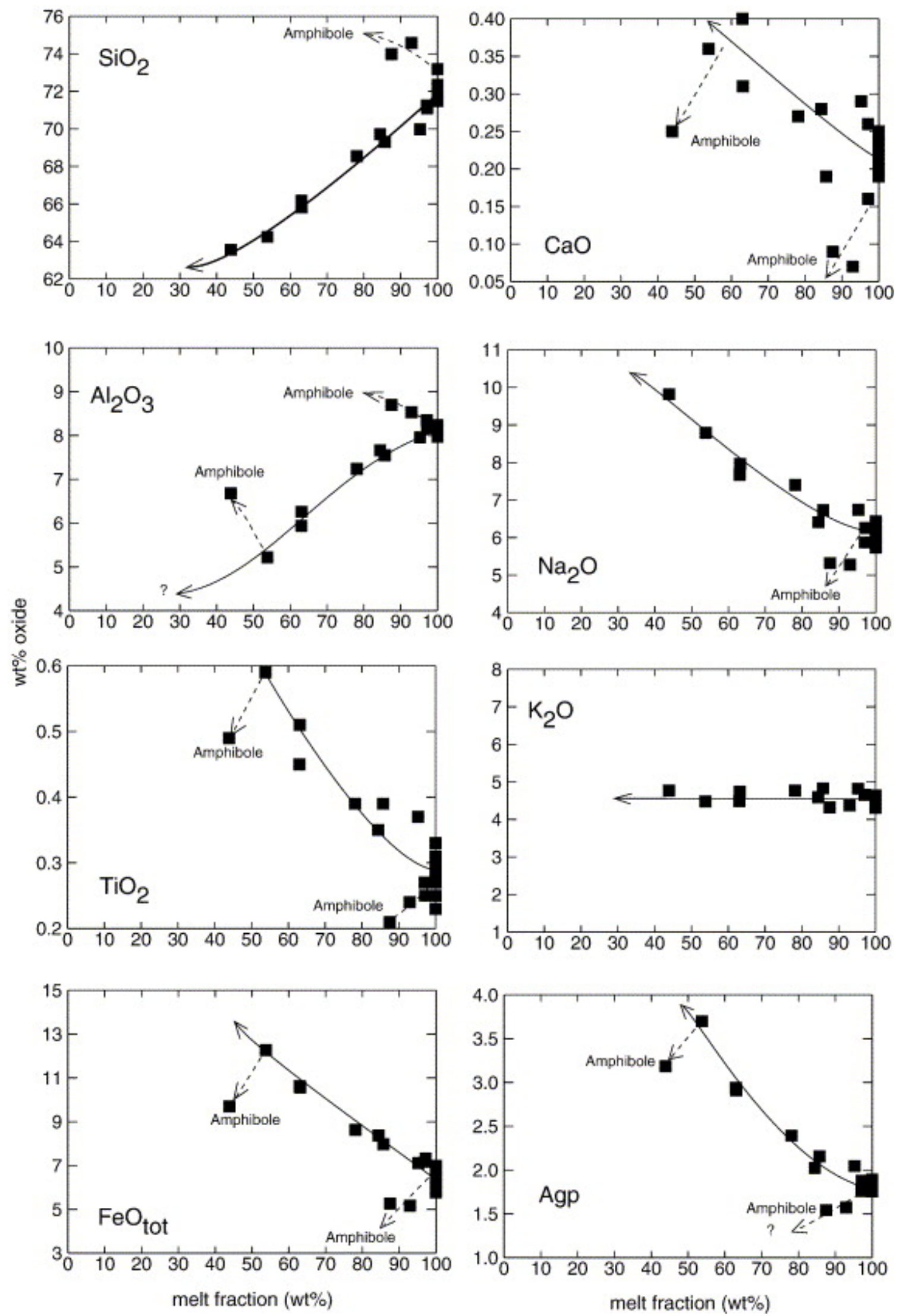

Fig. 5. Variation in the composition of the experimental glasses with crystallisation. The dashed lines show the effect of amphibole crystallisation on melt composition, either near the liquidus or under crystal-rich conditions. 
$\mathrm{Cl}$ and $\mathrm{F}$ abundances increase with crystallisation (Fig. 6). Although some scatter is apparent, in the most crystal-rich charges analysed $\mathrm{Cl}$ displays contents $(0.87 \mathrm{wt} . \%)$ similar to those predicted from incompatible behaviour $(0.89 \mathrm{wt} . \%)$ (Fig. 6). F follows broadly the same pattern, except when amphibole crystallises, which somewhat dampens the increase in F. However, the effect remains limited $(2.51 \mathrm{wt} . \%$ observed vs. $2.59 \mathrm{wt} . \%$ calculated in charge \#9, Table 2). The scatter in $\mathrm{F}$ contents at near-liquidus conditions, as compared to $\mathrm{Cl}$, may reflect some heterogeneity in $\mathrm{F}$ distribution in the starting glass
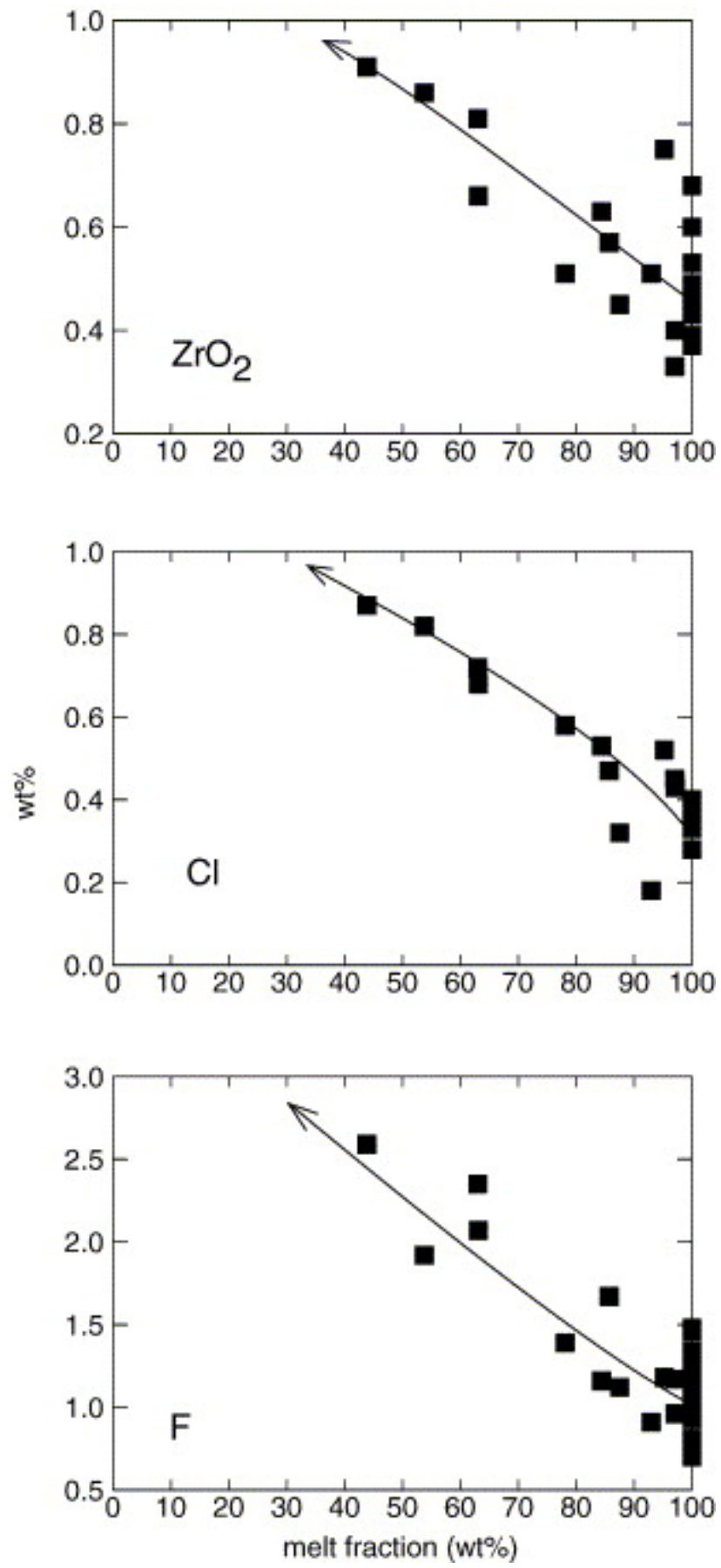

Fig. 6. Variation of $\mathrm{Cl}, \mathrm{F}$ and $\mathrm{ZrO}_{2}$ contents of the experimental glasses with crystallisation. 


\section{Discussion and conclusion}

\subsection{Equilibrium}

The present study uses the same approach as our previous experimental study of the Olkaria comendites, for which conditions close to equilibrium are believed to have been attained (Scaillet and Macdonald, 2001 and Scaillet and Macdonald, 2003). The use of dry glassy starting material, combined with the strongly perakaline character of the rhyolite, and the long run durations applied in our experiments, in excess of 49 days for the lowest temperature run, are all factors that should promote attainment of crystal-melt equilibrium in our charges. Observed mineral textures are equant, and minerals are evenly distributed across the charges. From the chemical viewpoint, the trends obtained are regular and vary in a consistent fashion with experimental variables $\left(T\right.$ and $\left.\mathrm{H}_{2} \mathrm{O}\right)$. We thus conclude that, as for the Olkaria experiments, the results presented here closely approach crystal-melt equilibrium.

\subsection{Liquid line of descent}

Our experiments define the general liquid line of descent of pantelleritic magmas stored at shallow pressure, under low $\mathrm{fO}_{2}$ conditions and for a variety of $\mathrm{H}_{2} \mathrm{O}$ contents. On the $\mathrm{Al}_{2} \mathrm{O}_{3}-$ $\mathrm{FeO}$ classification diagram of Macdonald (1974), the experimental glasses define a linear trend that extends the field defined by the rhyolites of the Eburru complex (Fig. 7). Also shown are the glasses obtained from the Olkaria experiments (Scaillet and Macdonald, 2003), whose most fractionated members were shown to closely approach the Eburru pantellerites. The present work shows clearly that fractionation of Eburru-type pantellerites yields melts that broadly follow the main trend defined by the Olkaria rocks (under reducing conditions). As for Olkaria, this trend of increasing $\mathrm{FeO}$ and concomitant decrease in $\mathrm{Al}_{2} \mathrm{O}_{3}$ seems limitless as long as only tectosilicates fractionate. The Eburru trend is, however, displaced to lower $\mathrm{Al}_{2} \mathrm{O}_{3}$ compared to that of the Olkaria rocks, a feature that was already apparent in the data of Scaillet and Macdonald (2003). This small difference indicates that, although Olkariatype comendites produce derivative liquids of clearly pantelleritic affinity, the comendite(s) parental to Eburru pantellerites must have been different from those erupted at the Olkaria complex. The small but perceptible difference in $\mathrm{Al}_{2} \mathrm{O}_{3}$ between the two groups of magmas possibly reflects a source signature or a pressure $/ \mathrm{pH}_{2} \mathrm{O}$-induced change in the feldspar/quartz ratio in the crystallising assemblage, affecting the rate of $\mathrm{Al}$ depletion in residual melts.

The Olkaria comendites are also precluded from being direct parents to the Eburru pantellerites by trace element characteristics. As well as having higher concentrations of most incompatible trace elements, they have higher LILE/HFSE ratios (Macdonald et al., 1987 and Clarke et al., 1990). 


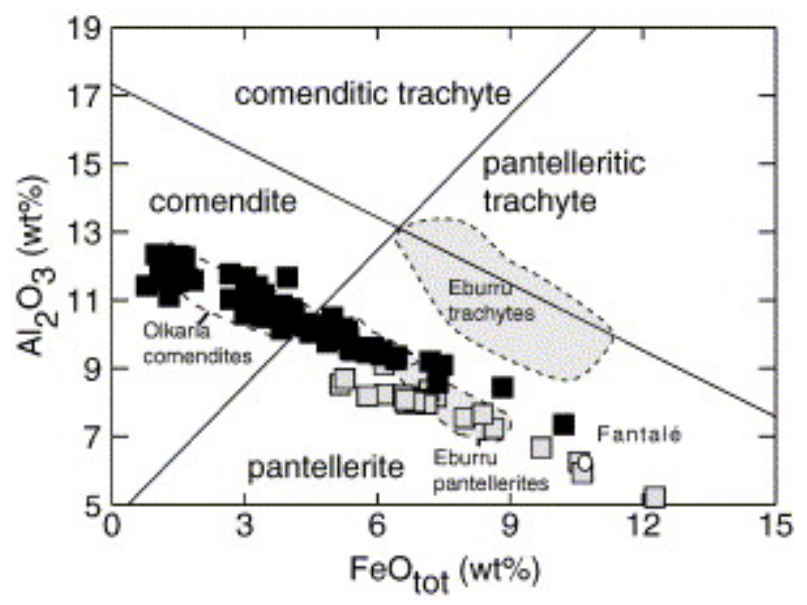

Fig. 7. $\mathrm{Al}_{2} \mathrm{O}_{3}-\mathrm{FeO}$ diagram showing the field of Eburru pantellerites and trachytes, together with the rhyolites of the Greater Olkaria Volcanic Complex. Superimposed are the experimental glasses obtained in this study (grey squares), by crystallising Eburru pantellerite and those from Olkaria rhyolite crystallisation (black squares) (Scaillet and Macdonald, 2001). Fields after Macdonald (1974). The Fantale pantellerite is from the Fantalé Volcano, Ethiopia (Lacroix, 1930).

From a broader perspective, the facts that pantellerites have lower liquidus temperatures than associated comendites and that they can be demonstrably derived from near-metaluminous rhyolites (Scaillet and Macdonald, 2003) indicate that the most iron- and sodium-rich pantellerites represent the true near-minimum melt composition of alkaline oversaturated series. The fact that most pantellerites are crystal-poor may be due to the exceedingly low viscosity that such magmas can achieve (Dingwell et al., 1998), in particular under $\mathrm{H}_{2} \mathrm{O}$-rich conditions such as at Eburru, which allows efficient melt-crystal separation. Any source that has the potential to produce peralkaline rhyolites will, upon initial melting, yield melts characterised by extreme enrichment in Fe, possibly with $\mathrm{FeO}$ contents $>10-12 \mathrm{wt} . \%$, low $\mathrm{SiO}_{2}$ contents ( $<63$ wt.\%, i.e. trachyte-like) and $\mathrm{Na}_{2} \mathrm{O}$ contents $\geq 10 \mathrm{wt} . \%$. Owing to their elevated iron and low silica contents, these first (last) drops of liquid might conceivably be quite dense compared to those produced at an advanced stage of melting (or early stages of crystallisation), during which Fe concentrations and thus the density of the liquid decrease. This peculiarity may explain why pantellerites with extreme chemical characteristics have rarely been observed to erupt as lava flows (i.e. Fantale, Fig. 7). Besides their low volume fraction, their relatively high density is likely to inhibit any crustal ascent, and they will remain trapped at depth. It would be instructive to study the compositions of the extrusive and intrusive rocks in individual volcanic-plutonic complexes, to try to determine if the intrusives are, in general, more Fe-rich than their erupted equivalents. In addition, the geochemical imprint of such hidden, denser liquids on the overall fractionation trends displayed by erupted oversaturated alkaline series remains to be explored quantitatively.

\subsection{Pre-eruption conditions}

Pre-eruption conditions can be assessed from the phase equilibrium results mainly because pantellerites tend to be sparsely phyric and phenocrysts do not display pronounced chemical zonation (i.e. alkali feldspar). In the present case, only amphibole is suitable to provide constraints on intensive parameters in the source reservoir. Unfortunately, as yet, there are no published chemical analyses of minerals of the Eburru pantellerites. The only such study of which we are aware is that of Ren et al. (2006-this issue), which provides first order constraints on the $T-f \mathrm{O}_{2}$ conditions of magma evolution at Eburru by the use of the QUILF geothermometer and oxybarometer. The authors report amphibole (ferrorichterite) in the 
phenocryst assemblage. As stressed above, the occurrence of amphibole phenocrysts in a crystal-poor pantellerite implies a restricted set of $T-\mathrm{H}_{2} \mathrm{O}$ conditions, basically below $700{ }^{\circ} \mathrm{C}$ and $\mathrm{H}_{2} \mathrm{O}_{\text {melt }}$ higher than 4 wt.\% (Fig. 2), if the pressure of magma storage is around $150 \mathrm{MPa}$. The temperature range retrieved from mineral equilibria in the Eburru pantellerites is 665$708^{\circ} \mathrm{C}$ (Ren et al., 2006-this issue), which agrees well with the phase equilibrium results. The lower end of the temperature range would imply $\mathrm{H}_{2} \mathrm{O}_{\text {melt }}>4 \mathrm{wt} . \%$. The constraints on temperature and melt $\mathrm{H}_{2} \mathrm{O}$ content are very similar to those derived for the Olkaria comendites (Scaillet and Macdonald, 2001), and therefore seem to characterise the regional pattern of magma storage and perhaps production in the Kenya Rift Valley. The fact that many peralkaline rhyolites erupt explosively (e.g., Ayalew et al., 2002 and Peccerillo et al., $\underline{2003}$ ) is also in agreement with their elevated water contents under pre-eruption conditions. The present work confirms that reduced magmas are not necessarily dry but may have significant amounts of dissolved water, comparable to those found in arc settings. The origin of the difference in $\mathrm{fO}_{2}$ between arc magmas and peralkaline rhyolites remains enigmatic, however. Perhaps it has to deal with the pronounced Fe-enrichment followed by transitional basalts upon crystallisation which, coupled to their lower $\mathrm{H}_{2} \mathrm{O}$ contents relative to arc basalts, helps peralkaline rhyolites to keep the reduced signature of their parental magma. The high $\mathrm{Fe}$ contents of residual liquids all the way down to the rhyolite stage may buffer the $\mathrm{fO}_{2}$ of alkaline magma series to low values.

\section{Acknowledgements}

RM thanks the Natural Environment Research Council (UK) for support of his Kenyan studies. Careful and useful reviews have been provided by Angelo Peccerillo and Mike Carroll. Gregor Markl is thanked for his efficiency in editorial handling and for his scientific input. Rémi Champallier is gratefully acknowledged for supplying the Eburru hydrous glass standards.

\section{References}

Albarède, 1995 F. Albarède, Introduction to Geochemical Modeling, Cambridge University Press (1995) 543 pp..

Andersen and Lindsley, 1988 D.J. Andersen and D.H. Lindsley, Internally consistent solution models for Fe-Mg-Mn-Ti oxides: Fe-Ti oxides, American Mineralogist 73 (1988), pp. 714 726.

Ayalew et al., 2002 D. Ayalew, P. Barbey, B. Marty, L. Reisberg, G. Yirgu and R. Pik, Source, genesis, and timing of giant ignimbrite deposits associated with Ethiopian continental flood basalts, Geochimica et Cosmochimica Acta 66 (2002), pp. 1429-1448.

Bailey, 1974 D.K. Bailey, Experimental petrology relating to oversaturated peralkaline volcanics: a review, Bulletin of Volcanology 38 (1974), pp. 635-652.

Bailey and Cooper, 1978 D.K. Bailey and J.P. Cooper, Comparison of the crystallisation of pantelleritic obsidians under hydrous and anhydrous conditions, Progress in Experimental Petrology, NERC Publications Series vol. 11 (1978), pp. 230-233. 
Bailey and Macdonald, 1969 D.K. Bailey and R. Macdonald, Alkali feldspar fractionation trends and the derivations of peralkaline liquids, American Journal of Science 267 (1969), pp. $242-248$.

Bailey and Macdonald, 1975 D.K. Bailey and R. Macdonald, Fluorine and chlorine in peralkaline liquids and the need for magma generation in an open system, Mineralogical Magazine 40 (1975), pp. 405-414.

Bailey and Macdonald, 1987 D.K. Bailey and R. Macdonald, Dry peralkaline felsic liquids and carbon dioxide flux through the Kenya Rift Zone. In: B.O. Mysen, Editor, Magmatic Processes: Physiochemical Principles, The Geochemical Society, Special Publication vol. 1 (1987), pp. 91-105.

Bailey and Schairer, 1964 D.K. Bailey and J.F. Schairer, Feldspar-liquid equilibria in peralkaline liquids - the orthoclase effect, American Journal of Science 262 (1964), pp. 1198 1206.

Bailey et al., 1974 D.K. Bailey, J.P. Cooper and J.L. Knight, Anhydrous melting and crystallisation of peralkaline obsidians, Bulletin of Volcanology 38 (1974), pp. 653-665.

Barclay et al., 1996 J. Barclay, M.R. Carroll, B.F. Houghton and C.J.N. Wilson, Pre-eruptive volatile content and degassing history of an evolving peralkaline volcano, Journal of Volcanology and Geothermal Research 74 (1996), pp. 75-87.

Burnham et al., 1969 C.W. Burnham, J.R. Holloway and N.F. Davis, Thermodynamic properties of water to $1000{ }^{\circ} \mathrm{C}$ and 10000 bar, Special Paper-Geological Society of America 132 (1969).

Carmichael, 1962 I.S.E. Carmichael, Pantelleritic liquids and their phenocrysts, Mineralogical Magazine 33 (1962), pp. 86-113.

Clarke et al., 1990 M.G.C. Clarke, D.G. Woodhall, D. Allen and G. Darling, Geological, Volcanological and Hydrogeological Controls on the Occurrence of Geothermal Activity in the Area Surrounding Lake Naivasha, Kenya, Ministry of Energy Report, Nairobi (1990) 138 pp..

Davies and Macdonald, 1987 G.R. Davies and R. Macdonald, Crustal influences in the petrogenesis of the Naivasha basalt-comendite complex: combined trace element and $\mathrm{Sr}-\mathrm{Nd}-$ Pb constraints, Journal of Petrology 28 (1987), pp. 1009-1031.

Dingwell et al., 1998 D.B. Dingwell, K.U. Hess and C. Romano, Extremely fluid behavior of hydrous peralkaline rhyolites, Earth and Planetary Science Letters 158 (1998), pp. 31-38.

Ghiorso and Sack, 1991 M.S. Ghiorso and R.O. Sack, Fe-Ti oxide geothermometry: thermodynamic formulation and the estimation of intensive variables in silicic magmas, Contributions to Mineralogy and Petrology 108 (1991), pp. 485-510.

Harris, 1986 C. Harris, A quantitative study of magmatic inclusions in the plutonic ejecta of Ascension island, Journal of Petrology 27 (1986), pp. 251-276. 
Heumann and Davies, 2002 A. Heumann and G.R. Davies, U-Th disequilibrium and Rb-Sr age constraints on the magmatic evolution of peralkaline rhyolites from Kenya, Journal of Petrology 43 (2002), pp. 557-577.

Johannes and Holtz, 1996 W. Johannes and F. Holtz, Petrogenesis and Experimental Petrology of Granitic Rocks, Springer Verlag (1996) 335 pp..

Kovalenko et al., 1988 V.I. Kovalenko, R.L. Hervig and M.F. Sheridan, Ion-microprobe analyses of trace elements in anorthoclase, hedenbergite, aenigmatite, quartz, apatite and glass in pantellerite: evidence for high water contents in pantellerite melts, American Mineralogist 73 (1988), pp. 1038-1045.

Lacroix, 1930 A. Lacroix, Les roches hyperalcalines du massif du Fantalé et du col de Balla, Mémoires de la Société Géologique de France 14 (1930), pp. 89-102.

Leake et al., 1997 B.E. Leake, Nomenclature of amphiboles. Report of the subcommittee on amphiboles of the International Commission on new minerals and mineral names, European Journal of Mineralogy 9 (1997), pp. 623-651.

Lowenstern and Mahood, 1991 J.B. Lowenstern and G.A. Mahood, New data on magmatic $\mathrm{H}_{2} \mathrm{O}$ contents of pantellerites, with implications for petrogenesis and eruptive dynamics at Pantelleria, Bulletin of Volcanology 54 (1991), pp. 78-83.

Macdonald, 1974 R. Macdonald, Nomenclature and petrochemistry of the peralkaline oversaturated extrusive rocks, Bulletin Volcanologique 38 (1974), pp. 498-516.

Macdonald and Bailey, 1973 R. Macdonald and D.K. Bailey, The chemistry of the peralkaline oversaturated obsidians, U.S. Geological Survey Professional Paper 440-N (1973) (Part 1), pp. 1-37.

Macdonald et al., 1987 R. Macdonald, G.R. Davies, C.M. Bliss, P.T. Leat, D.K. Bailey and R.L. Smith, Geochemistry of high-silica peralkaline rhyolites, Naivasha, Kenya Rift Valley, Journal of Petrology 28 (1987), pp. 979-1008.

Mahood, 1984 G.A. Mahood, Pyroclastic rocks and calderas associated with strongly peralkaline magmatism, Journal of Geophysical Research 89 (1984), pp. 8540-8552.

Mungall and Martin, 1996 J.E. Mungall and R.F. Martin, Extreme differentiation of peralkaline rhyolite, Terceira, Azores: a modern analogue of Strange Lake, Labrador?, The Canadian Mineralogist 34 (1996), pp. 769-777.

Peccerillo et al., 2003 A. Peccerillo, M.R. Barberio, G. Yirgu, D. Ayalew, M. Barbieri and T.W. Wu, Relationships between mafic and peralkaline silicic magmatism in continental rift settings: a petrological, geochemical and isotopic study of the Gedemsa Volcano, Central Ethiopia Rift, Journal of Petrology 44 (2003), pp. 2003-2032.

Ren et al., 2006-this issue M. Ren, P.A. Omenda, E.Y. Anthony, J.C. White, R. Macdonald and D.K. Bailey, Application of the QUILF thermobarometer to the peralkaline trachytes and pantellerites of the Eburru volcanic complex, East African Rift, Kenya, Lithos (2001). 
$\underline{\text { Robie et al., } 1979}$ R.A. Robie, B.S. Hemingway and J.R. Fisher, Thermodynamic properties of minerals and related substances at $298.15 \mathrm{~K}$ and 1 bar (105 Pascals) pressure and at higher temperature, US Geological Survey Bulletin 1452 (1979).

Scaillet and Macdonald, 2001 B. Scaillet and R. Macdonald, Phase relations of peralkaline silicic magmas and petrogenetic implications, Journal of Petrology 42 (2001), pp. 825-845.

Scaillet and Macdonald, 2003 B. Scaillet and R. Macdonald, Experimental constraints on the relationships between peralkaline rhyolites of the Kenya Rift Valley, Journal of Petrology 44 (2003), pp. 1867-1894.

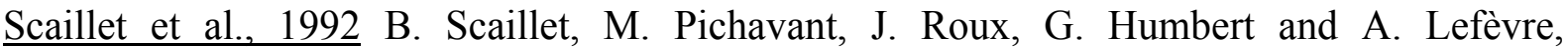
Improvements of the Shaw membrane technique for measurement and control of $\mathrm{fH}_{2}$ at high temperatures and pressures, American Mineralogist 77 (1992), pp. 647-655.

Schmidt et al., 1995 B.C. Schmidt, B. Scaillet and F. Holtz, Accurate control of $f \mathrm{H}_{2}$ in cold seal pressure vessels with the Shaw membrane technique, European Journal of Mineralogy 7 (1995), pp. 893-903.

Webster et al., 1993 J.D. Webster, R.P. Taylor and C. Bean, Pre-eruptive melt composition and constraints on degassing of a water-rich pantellerite magma, Fantale Volcano, Ethiopia, Contributions to Mineralogy and Petrology 114 (1993), pp. 53-62.

Wilding et al., 1993 M.C. Wilding, R. Macdonald, J.R. Davies and A.E. Fallick, Volatile characteristics of peralkaline rhyolites from Kenya: an ion microprobe, infrared spectroscopic and hydrogen isotope study, Contributions to Mineralogy and Petrology 144 (1993), pp. 264 275. 